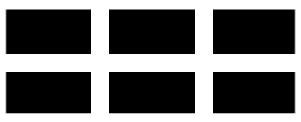

ThE WiLliam DAVIDSON INSTITUTE AT THE UNIVERSITY OF MICHIGAN BUSINESS SCHOOL

Bank Discrimination in Transition Economies: Ideology, Information or Incentives?

\author{
By: Loren Brandt and Hongbin Li
}

William Davidson Working Paper Number 517

October 2002 


\title{
Bank Discrimination in Transition Economies: Ideology, Information or Incentives?*
}

\author{
Loren Brandt ${ }^{\dagger} \quad$ Hongbin $\mathrm{Li}^{\ddagger}$
}

October 1, 2002

*Acknowledgements: We would like to thank Albert Park, Joanne Roberts, Minggao Shen, and Lian Zhou for their valuable comments. We are indebted to the William Davidson Institute and the Ford Foundation in Beijing for funding the survey work in 1998. Brandt also thanks Canadia's Social Sciences and Humanities Research Council for support.

${ }^{\dagger}$ Corresponding author, Department of Economics, University of Toronto; Address: 150 St. George Street, Toronto, ON M5S 3G7, CANADA. Tel.: 416-978-4442; Fax: 416-978-6713; Email: brandt@chass.utoronto.ca

$\ddagger$ Department of Economics, The Chinese University of Hong Kong. 


\title{
Bank Discrimination in Transition Economies: Ideology, Information or Incentives?
}

\begin{abstract}
We study bank discrimination against private firms in transition countries. Theoretically, we show that banks may discriminate for non-profit reasons, but this discrimination diminishes with a bank's incentives and human capital. Employing matching bank-firm data from China, we empirically examine the extent, sources and consequences of discrimination. Our unique survey design allows us to disentangle sample truncation, omitted variable bias, and endogeneity issues. Our empirical findings confirm the theoretical predictions. We also find that as a result of discrimination, private firms resort to more expensive trade credits.
\end{abstract}

Key words: Bank discrimination; privatization; economic transition JEL Classification Codes: G14, G21 P26 P34 


\section{Introduction}

The role of the banking sector in the process of economic transition is well recognized. Bank behavior largely determines the hardness of the budget constraints facing enterprises, and thus, firm incentives. Banks also play an important role in the intermediation of savings, and the allocation of credit to existing and especially newly established firms. Indeed, it is because of these links and the banking systems' potential effects on the real sector that some observers have argued for the need for enterprise restructuring, privatization, and bank reform to go hand-in-hand (Brainard, 1991).

Since the early 1990s, the private sector has been the most dynamic sector of the Chinese economy. Between 1990 and 2000, the average annual growth rate of output in this sector was almost 60 percent (China Statistical Yearbook; Zhang and Ming, 2001). ${ }^{1}$ This sector includes not only de novo private firms, but also many State Owned Enterprises (SOEs), and especially Township and Village Enterprises (TVEs) that were privatized since 1993 (Cao, Qian and Weingast, 1999; Nyberg and Rozelle, 2001). ${ }^{2}$ By the end of 2000, the private sector was producing more than one-third of China's industry output.

Although the private sector is growing rapidly, borrowing from China's state-owned commercial banking sector by private firms remains meager. ${ }^{3}$ According to a recent World Bank Report (2000), in the late 1990s the private sector received less than one percent of the total lending of China's commercial banks. ${ }^{4}$ Most investment and working capital are financed through retained earnings, informal networks, and inter-firm credit (Lardy, 1998; Zhang and Ming, 2001). The sharp contrast between private sector growth and the loans the sector receives from the banking system raises a fundamental question: Are private firms being discriminated against in the formal financial markets? If so, why?

\footnotetext{
${ }^{1}$ These numbers are slightly misleading because of the very low base from which they are calculated, however, it remains the case that private firms grew rapidly over this period.

${ }^{2}$ In the 1980s, the TVE sector was the most rapidly growing segment of the economy.

${ }^{3}$ China's banking sector is dominated by four state-owned banks, namely, the Bank of China, Industrial and Commercial Bank of China, Construction Bank of China, and the Agricultural Bank of China. Rural areas are also served by the Rural Credit Cooperatives, while the Urban Commercial Banks (formerly, the Urban Credit Cooperatives) also service urban areas.

${ }^{4}$ These figures may underestimate the lending to the private sector, however, it is still the case that state and collectively-owned firms are receiving a disproportionate share of the credit.
} 
This paper tackles the question of bank discrimination against private firms, drawing on a unique matching bank-firm data set collected by the authors in rural China in 1998 . Bank behavior in China towards private firms has potentially important implications for the ongoing privatization process, and economic growth, more generally (Brandt and Zhu, 2000 and 2002). It also has implications for financial sector reform.

Our analysis makes several contributions to the literature on discrimination and transition economies. First, this paper is one of the first studies of ownership discrimination in the formal loan market. Most of the existing literature looks at gender or racial discrimination. Second, our data allow us to identify potential sources of discrimination, notably, bank manager incentives and attributes. Although the banking system in China is undergoing reform, heterogeneity at the local level in this process gives rise to significant institutional differences across localities, especially with respect to bank manager incentive systems. We exploit these differences to help identify differences in bank lending behavior across ownership groups. Third, our survey and sampling design allow us to deal with a number of common econometric problems encountered in the literature on bank discrimination, notably, the role of demand side effects on lending behavior and an under-sampling of certain groups (here, private firms). Finally, we use additional information on the firm's entire debt structure to investigate "market" discrimination of private firms as opposed to discrimination of these firms by a single bank. As Becker (1957) and Heckman (1998) note, it is at the margin, i.e. where firms actually borrow, that economic values are set.

The structure of the paper is as follows. Section 2 briefly surveys the literature on bank discrimination. Section 3 describes financial institutions and firms in rural China. Section 4 builds a simple theoretical model that generates predictable hypothesis of ownership discrimination. Section 5 introduces the survey and the data. Sections 6,7 and 8 econometrically examine the extent, consequences, and sources of discrimination. Section 9 concludes. 


\section{Literature Review}

Three central issues dominate the discrimination literature. First, how do you define discrimination? Second, what are its sources? And third, how do you empirically test for it?

There are a number of alternative definitions of discrimination. On the one hand, there is a strictly legal notion. The American civil rights law, for example, defines discrimination as the unfavorable treatment of a person solely on the basis of that person's membership in a "protected class" (Yinger, 1998). There is also an analytical definition. Following Becker (1993), discrimination in the market place consists of "voluntarily relinquishing profits, wages or income to cater to prejudice." In this paper, we will draw largely on the analytical definition.

These definitions entertain a number of alternative sources of discrimination. The first and most obvious source is simply discrimination by tastes (Arrow, 1998; Becker, 1957; Yinger, 1998). Banks may discriminate against a certain group because they dislike the applicants for cultural or historical reasons. In China, banks are state-owned, and may have a purely ideological preference for lending to government-owned firms over private firms. Lending to government-owned firms may also generate perks to banks that do not exist when lending to private firms. More generally, banks may be willing to sacrifice profits in order to seek political, ideological or personal goals rather than the bank's profits. The lack of competition in China's banking system may help to sustain such behavior.

Second, differences in lending may arise because banks possess better information on a certain group of loan applicants (Arrow, 1998; Fafchamps, 2000). When it is costly to acquire information about an applicant's true credit worthiness, banks may base their decisions on group characteristics. This is the basis for statistical discrimination (Schwab, 1986; Arrow, 1998; Darity and Mason, 1998; Yinger, 1998). If the credit history of a certain group is bad, then all members in that group will face discriminatory behavior. In China, banks have been dealing almost exclusively with government-owned firms, and have developed good channels for obtaining credit information about these firms. Newly established, private firms 
might find themselves at a disadvantage in this regard, and individually face discriminatory behavior by banks.

There are two other reasons why private firms may face difficulty in accessing formal sector credit. In both of these cases, however, differential treatment of private firms by banks might be defended on profitability grounds. First, discrimination in other markets can affect bank-lending decisions. If a certain group is discriminated against in either the input or product markets, then it is more likely for the loan applicants in this group to default. Knowing there exists such discrimination, banks may decide not to lend to loan applicants in this group (Ladd, 1998; Loury, 1998). In addition, banks may discriminate against private firms because they are perceived as being riskier than government-owned firms, which pool risks together (Park and Shen, 2002). In the event of default, the government can use either fiscal resources or funds from other government-owned firms to repay a firm's loan.

The empirical literature analyzing discrimination against minorities and women in the mortgage and small business loan markets is directly related to the question we tackle. Employing OLS, Probit or Logit models of loan denial rates, Yinger (1986), Munnell (1996) and Blanchflower et al. (1998) find that the race (gender) dummies are significantly positive, which implies that women and minorities are less likely to get loans, all else equal. Interpreting these findings as "discrimination" is potentially problematic however. The main concern is that these regressions may exclude variables that are important in the banks' lending decisions, most notably, measures of credit worthiness. This omission gives rise to omitted variable bias in the estimates of the effect of race and gender (Neal and Johnson, 1996; Heckman, 1998; Darity and Mason, 1998; Yinger, 1998), and can lead the researchers to conclude that groups are being discriminated against, when in fact they are not.

There are a number of methods for dealing with unobserved variable bias. The first and also the most direct method is simply to find good measures for credit worthiness (Munnell et al., 1996), and include them as additional controls in the regression. The second method is to check to see if there is "equal treatment" for loan receivers (Blanchflower et al., 1998; Ladd, 1998). If the study group has to pay a higher interest rate, or meet a higher loan 
standard, all else equal, then discrimination against this group can be inferred. The third method is to examine if other creditors are also unwilling to provide loans to the study group (Blanchflower et al., 1998). The fourth method is to compare the default rate of the study group with that of the control group (Ladd, 1998). If a group of loan applicants is discriminated against, then only the more credit-worthy applicants in the group should be able to obtain bank loans. This suggests that the ex post loan performance of the study group should be better than the control group.

Sample design issues, notably, the use of data on only loan applicants, introduce potentially offsetting biases (Heckman, 1998). Suppose there is a cost of a loan application, which is the same for both groups. If individuals (firms) in the study group believe that the probability of getting a loan is low, they may not be willing to incur the cost of the application. If, as a result, many individuals (firms) in the study group decide not to apply, using a sample of loan applicants will under-estimate the effect of discrimination because the only individuals (firms) in the study group that apply are those who are most likely to get a loan. A solution to this problem is to obtain information on the demand for loans for all firms, and not just those that applied for a loan.

Finally, Heckman (1998) argues that discrimination by a randomly selected party (a bank in our case) does not necessarily imply market discrimination. A particular financial institution may not want to lend to a private firm, but if other financial institutions are willing to lend and on as good as terms, then discrimination is not an issue. What matters is the behavior of the marginal lender or set of lenders. This suggests that we will want to look at a firm's access to all sources of credit, and their entire debt structure, and not just that from banks.

\section{Financial Institutions and Firms in Rural China}

Two financial institutions dominate the formal financial system in rural China: The Agricultural Bank of China (ABC), and the Rural Credit Cooperatives (RCC). As of the late 1990s, these two institutions held nearly eighty percent of all rural deposits, and were the 
source of an equal percentage of loans, nearly half of which went to local township and village enterprises (Park, Giles and Brandt, 1997).

The $\mathrm{ABC}$ is one of the four specialized state-owned banks and historically was responsible for lending to support agriculture and rural development. Branches are located in almost every township in rural China. ${ }^{5}$ Officially, the RCCs are autonomous, collectively-run local institutions, but up through the early 1990s were usually supervised by local ABC branches. In some cases, the same individual managed the two institutions. However, in 1994 the supervision of the RCCs shifted to China's central bank, the People's Bank of China (PBC), and the separation between the RCCs and ABCs became more distinct.

Township level branches of the ABC report to county level branches of the same bank; RCCs, on the other hand, report to county-level RCC associations (xinyong lianshe). For both financial institutions, township branch managerial incentives, loan size limits, credit quotas, etc. are set at the county level. ABC and RCC township managers are also appointed by banking authorities at the county level, but in both cases, township-level governments and party officials can exercise important influence over these decisions. Unlike the lending to state-owned enterprises by state-owned banks, however, lending to township and village enterprises was not administratively mandated as part of a credit plan.

Throughout the 1980s and early 1990s, enterprises that were owned and managed by township and village governments (TVEs) dominated China's rural industrial sector (Che and Qian, 1998; Chen and Rozelle, 1999). Beginning in 1993, local governments were given permission to privatize these firms as part of a nationwide policy on enterprise ownership restructuring, or zhuanzhi. Previously, privatization was strictly prohibited. Reflecting the high degree of administrative decentralization in China, local governments were effectively given discretion as to how to interpret and carry out the new policy. By the end of the 1990s, nearly two-thirds of all TVEs had been privatized in the provinces in which we surveyed, though considerable differences exist across townships in the extent of privatization.

\footnotetext{
${ }^{5}$ The township (town) is the lowest level of government in China's administrative hierarchy, with the county immediately above.
} 


\section{The Model}

In this section, we consider a stylized model of bank monitoring, which links bank discrimination against private firms to non-profit incentives. The model also generates testable hypotheses: Discrimination diminishes with a bank manager's incentives and human capital. Although we only model ex post monitoring and do not consider the role of ex ante bank screening, we test empirically whether information is an important source of discrimination.

Consider a simple model of bank lending. Suppose that there are $2 \mathrm{~N}$ firms in the economy, half are Township Enterprises (TEs), and the other half are Private Enterprises (PEs). Assume the N TEs are identical to the N PEs in all respects other than ownership. Each firm has a project that requires an investment of 1 unit, which it finances in full by borrowing from the bank at a fixed (gross) interest rate $r$.

A firm's project generates stochastic returns. If a project succeeds, it generates a payoff larger than $r$; and if it fails, it generates nothing. The probability of a successful project is $\beta$, where $\beta$ also represents a firm's profitability type. A successful project does not mean that the loan will be repaid since firms can also strategically default (Park and Shen, 2002). Suppose that the probability of a firm strategically defaulting is $1-e$, where $e$ is the bank manager's monitoring effort. The cost of monitoring is $C(e) / b$, where $C^{\prime}(e)>0, C^{\prime \prime}(e)>0$. The parameter $b$ represents bank manager ability, with monitoring costs decreasing in $b$. Assuming that $\beta$ and $e$ are independent, the probability of the bank getting repaid is $\beta e$, which increases with both $\beta$ and $e$, where $\beta$ and $e$ are complementary. Assume that $\beta$ for TEs and PEs has the same distribution, and is distributed on $[0, \bar{\beta}]$.

The bank's profit from lending to a firm is $\beta e r-1$. For a PE, the bank manager cares about the profitability of lending only, thus the utility of lending to a PE is

$$
U_{1}=a(\beta e r-1)-C(e) / b
$$

where $a$ is the profit incentive of the bank manager. For a TE, however, the bank also cares about the perks generated from lending, $L{ }^{6}{ }^{6}$ These perks are tied to the bank manager's

\footnotetext{
${ }^{6}$ This follows the formulation of Becker (1957), in which an economic agent cares about taste on top of profits.
} 
relationship with township government leaders. Thus, the bank's utility when lending to a $\mathrm{TE}$ is

$$
U_{2}=a(\beta e r-1)-C(e) / b+L
$$

It is easily seen that if a TE and a PE are equally profitable, with the same $\beta$, then the bank will exert the same optimal effort, $e^{*}$, in both firms. Since there is a lump-sum perk from lending to a TE, the bank prefers a TE in this case. ${ }^{7}$

The bank has enough funding for $M$ firms, where $M<2 N$. So only some of the firms will be financed. The bank maximizes the sum of utility from each of the $M$ firms to which it lends, or

$$
\sum Y_{i} U_{1 i}+\sum Y_{j} U_{2 j}
$$

Here $Y=1$ if a firm receives a loan, and $Y=0$ otherwise; and $i$ and $j$ are indexes for a PE and TE, respectively. Assume for simplicity that the total effort is less than the available effort, or $\sum e_{i}^{*}+\sum e_{j}^{*}<\bar{e}{ }^{8}$ We will show in this case that the marginal PE being financed is more profitable than the marginal TE being financed. Define $\beta_{1}$ and $\beta_{2}$ as the profit types of the marginal PE and TE that get bank loans. In other words, for firms that get loans, $\beta_{1}$ is the lowest profit type of a $\mathrm{PE}$, and $\beta_{2}$ is the lowest profit type of a TE. We can summarize the above argument in Proposition 1. Proofs of propositions are in the appendix.

PROPOSITION 1: When there are only perks for lending to TEs, banks will discriminate against PEs. This is reflected in the fact that the marginal PE being financed is more profitable than the marginal TE being financed, or $\beta_{1}>\beta_{2}$.

The intuition of Proposition 1 is simple. The bank chooses firms to lend so as to maximize its total utility. The process of choosing firms can be described as first ranking all firms by the maximized bank utility from lending to each firm, and then picking the $\mathrm{M}$ top-ranking firms. The marginal PE and marginal TE have to generate the same utility for the bank, otherwise, the bank can increase its total utility by lending to more (less) of the firms in the

\footnotetext{
${ }^{7}$ Algebraically, since the maximized utility is $U_{2}\left(e^{*}\right)=a\left(\beta e^{*} r-1\right)-C\left(e^{*}\right) / b+L$ for a TE, but $U_{1}\left(e^{*}\right)=$ $a\left(\beta e^{*} r-1\right)-C\left(e^{*}\right) / b$ for a $\mathrm{PE}, U_{1}\left(e^{*}\right)-U_{2}\left(e^{*}\right)=L>0$.

${ }^{8}$ This assumption can be justified if it is easier for banks to hire additional people to monitor firms than to obtain more funds for lending. In fact, funding is typically a bottleneck for these banks.
} 
ownership group with the high (low) marginal utility. Because lending to a TE generates perks, the marginal $\mathrm{PE}$ has to be more profitable than the marginal $\mathrm{TE}$, or $\beta_{1}>\beta_{2}$. This means that more TEs than PEs get bank loans, and that the average profitability of TEs is lower than PEs. Proposition 1 also implies that bank effort in the marginal PE is higher than that in the marginal TE. This is Lemma 1.

LEMMA 1: Effort in the marginal PE is higher than that in the marginal TE, or $e_{1}^{*}>e_{2}^{*}$.

Lemma 1 follows immediately from Proposition 1. Since incentives and effort are complementary, larger incentives in the marginal PE mean a larger effort level. We will use Lemma 1 to conduct some simple comparative statics, which illustrate how discrimination changes with the change of parameters a, b and L. The comparative statics are summarized in Proposition 2.

PROPOSITION 2: The degree of discrimination decreases with the bank manager's incentives, a, bank manager's ability, b, and increases with the amount of perks, L. At the same time, there will be more PEs and less TEs being financed, and the average profitability of lending will increase. Algebraically, $\partial \beta_{1} / \partial a<0, \partial \beta_{2} / \partial a>0 ; \partial \beta_{1} / \partial b<0, \partial \beta_{2} / \partial b>0$; $\partial \beta_{1} / \partial L>0, \partial \beta_{2} / \partial L<0$

The intuition for the change of incentives is straightforward. When incentives increase, banks will exert more effort monitoring all firms that receive loans, and the increase of effort, together with the increase of incentives, increases the maximized utility of lending to each firm. This argument also applies for the marginal PE and TE. But, since the marginal $\mathrm{PE}$ is of larger profit type than the marginal TE, and firm profit type and effort are both complementary with incentives, the increase of utility for the marginal $\mathrm{PE}$ is larger than that for the marginal TE, or $\partial U_{1}^{*} / \partial a>\partial U_{2}^{*} / \partial a$. This implies that with the increase of incentives, the utility of lending to the old marginal PE is larger than that of lending to the old marginal TE. In order to equalize the utility of lending to the two marginal firms, the bank has to lower the profitability of the marginal PE and increase that of the marginal TE. This change not only reduces discrimination, but also improves the total profitability of the 
bank since the new PEs getting bank loans are better than those old TEs that lose their loans.

The change of the bank manager's ability has a similar effect. When a manager's ability increases, they will exert more effort monitoring the marginal firms, which increases the maximized utility of each firm. But, since ability and effort are complementary, the increase of utility for the marginal PE is larger than that for the marginal TE, or $\partial U_{1}^{*} / \partial b>\partial U_{2}^{*} / \partial b$. This implies that with the increase of ability, the utility of lending to the marginal PE is larger than that of lending to the marginal TE. In order to equalize the two, the bank has to lower the profitability of the marginal PE and increase that of the marginal TE. This means that fewer TEs get loans than before, while more PEs get loans than before.

The effect of a change of perks is more direct. A decrease of bank perks does not change bank efforts for each firm, but it decreases the utility of lending to a TE. In order maintain equality between the utility of lending to a marginal TE and PE, the bank has to lower the profitability of the marginal PE and increase that of the marginal TE.

\section{The Data}

The data we use are drawn from a bank-firm survey the authors conducted with Chinese colleagues in the summer of 1998. The survey was carried out in 59 townships in 15 counties in the coastal provinces of Jiangsu and Zhejiang, and focused on the period between 1994 and 1997. The selection of the counties and townships was designed to ensure a representative cross-section of the region. The unique dimension of the survey is the matched firm-bank data.

In each township, we randomly sampled three firms from the pool of all TEs that operated in 1994, as well as all private firms that were of comparable size. ${ }^{9}$ We interviewed each firm manager in length about their firm, including bank borrowing, and also collected detailed data on the firm's operations, e.g. employment, sales, and financial assets and liabilities.

Altogether, 168 firms were randomly selected and surveyed, or three per township. Out of these firms, 33 were established as private firms (henceforth private firms or PEs). The

\footnotetext{
${ }^{9}$ Enterprises were required to have at least 20 employees and a minimum fixed capital of 200,000 RMB.
} 
remaining 135 firms were originally set up and owned by the local township government (henceforth township enterprises or TEs). Between 1994 and 1997, however, 88 out of these 135 firms were sold off to private owners, and became privatized firms. Privatization, in our paper, means that majority ownership shifted from the government to private individuals. As noted above, 1994 effectively marks the beginning of privatization efforts in the region. At the end of 1997, 47 firms remained government-owned.

We also surveyed the township branch of the Agricultural Bank of China (ABC), and the local Rural Credit Cooperative (RCC). Data on ABC and RCC lending to each of the surveyed firms were obtained. We also collected information on bank managers, their incentive structures, and branch performance, the latter primarily in the form of detailed balance sheet data. There are considerable differences across townships with respect to managerial incentives, role of profitability, etc., heterogeneity that we exploit later in the paper.

Finally, we also have credit rating information on our sample of firms from each of the banks. This unique feature of the data allows us to control for the credit worthiness in our regressions. The credit rating is on a scale from 1-6 (6 is the highest ranking) and was constructed separately by each bank for each firm.

\section{Does Ownership Matter?}

If private and privatized firms are discriminated against, we expect to find that they are less likely to get a bank loan and/or obtain smaller loans, all else equal. Banks may also apply a higher lending standard for private and privatized firms. We will examine both the probability of a firm obtaining a bank loan and loan application requirements.

\subsection{Probability of having a bank loan}

In Table 1, we report summary data for 1994 and 1997 on loans from the ABC and RCC branches by ownership group for 152 out of our sample of 168 firms. ${ }^{10}$ There are stark differences in both years in access to credit between private and township enterprises. In

\footnotetext{
${ }^{10}$ We lose 16 observations due to missing values for some variables.
} 
1994, more than half (56 percent) of all private firms did not receive a loan from either bank branch; slightly more than a third (38 percent) received a loan from one of them; and 6 percent received loans from both. In contrast, slightly more than 80 percent of all township enterprises received loans, with a third actually receiving loans from both institutions. ${ }^{11}$ There are also significant differences in the size of loans received. On average, township enterprises received four times as much credit as private firms (1.65 million RMB versus 0.43 million RMB).

These differences carry through using the data for 1997, with one important addition: Between 1994 and 1997, a widening gap emerges in the average amount of credit received by township enterprises and those township enterprises that were subsequently privatized. In 1994, the difference was 0.63 million RMB; by 1997, it had increased to 1.61 million. Over this three-year period, credit to privatized TEs failed to increase. In general, the data in Table 1 show that most of the new credit extended by ABC and RCC branches between 1994 and 1997 to the firms in our sample went to the 39 township enterprises that remained under government ownership.

To analyze more formally the effect of ownership on credit access, we estimate separate probit models for 1994 and 1997 of the probability of a firm obtaining a bank loan. We also report Tobit estimates on loan size for comparison. The convention in the literature is to estimate loan denial equations, based on bank loan application data. The problem with this approach is that it excludes firms that may not have applied because they expected their application to be rejected. In our empirical work, we include all firms that reported that they demanded loans from the $\mathrm{ABC}$ or RCC. The implicit assumption here then is that banks were not willing to lend to those firms that reported that their bank loans were equal to zero.

The key to identifying the effect of ownership on firm access to credit is to control for firmlevel variables, e.g. credit worthiness, which are also likely correlated with firm borrowing. Failure to do so adequately can result in a potential omitted variable bias in our estimation of the effect of ownership on credit access, and lead us to confer too much weight on its effect

\footnotetext{
${ }^{11}$ Recall that in 1994 township firms include firms identified in Table 1 as "Privatized TEs".
} 
in bank decision-making. Our survey provides information on each firm's assets, sales, age, debt-asset ratio, capital-labor ratio, and bank credit rating, in addition to information on the manager's education and experience. Table A1 provides summary data on these variables for our three ownership groups.

Tables 2 and 3 report the results from our Probit and Tobit analysis for 1994 and 1997, using several alternative sets of firm-level controls. ${ }^{12}$ In each regression, we also include a set of dummies for industry sector, bank type (ABC or RCC), and province. As a benchmark, we report the Probit and Tobit results with only the ownership dummies included, and controls for bank type, province and industry sector. The parameter estimates for the effect of ownership for each year are consistent across the rows of Table $2 .{ }^{13}$ For 1994, private firms were nearly sixty percent less likely to obtain a loan compared to township enterprises. On average, they received 250,000 RMB less in loans than a comparable TE. There are no differences, however, in the likelihood of credit access or loan size between township enterprises, and those township enterprises that were later privatized. In 1997, private firms are again less likely than government-owned firms in obtaining credit, albeit slightly lower than in 1994, i.e. fifty percent vs. sixty percent. The gap in loan size, however, nearly doubled. Note, however, that in 1997 township enterprises that were privatized during the previous three years experienced a significantly lower probability of receiving a bank loan than firms that remained under government-ownership. Moreover, they also received considerably smaller loans than TEs.

\subsection{Firms' credit ratings}

In our regressions, the most important control variable measuring a firm's credit worthiness is the firm's credit rating, which has a positive and significant effect in each of the probit regressions for 1997. The credit rating, which is a score given by each bank to a firm, is based on the firm's past credit history, profitability, sales, and the firm manager's attributes. If

\footnotetext{
${ }^{12}$ We only have credit rating information for 1994 for a small subset of firms, and so use the 1997 credit rating in the 1994 regressions. For those firms for which we have credit rating information for both years, the ratings are very similar. Using the 1997 credit rating in the regression for 1994 will not introduce any bias as long as access to credit in 1994 does not by itself influence the credit rating in 1997.

${ }^{13}$ We report the marginal effect on probability of each independent variable $(d F / d x)$ rather than estimated coefficients.
} 
private and privatized firms indeed are less creditworthy, then including their credit rating as a control variable should reduce the magnitude of the coefficients on the ownership indicators significantly.

The regression results in Table 2 indicate, however, that private and privatized firms may not be less creditworthy. Including the credit rating has a negligible effect on the coefficients of the ownership indicators (column 2 vs. 3). Private and privatized firms remain significantly less likely to have access to credit from the $\mathrm{ABC}$ or $\mathrm{RCC}$, and are lent less. This suggests that the credit ratings of private and privatized firms are fairly similar to those of township enterprises.

To further examine if ownership itself is an important determinant of a firm's credit rating, we estimated the firm's credit rating function using OLS. The independent variables include those in Table 2 and measures of a firm's credit history and performance. If we find that private and privatized firms have lower credit ratings, all else equal, there are two potential reasons. First, it could be that banks observe certain credit qualifications that are unobservable to the econometrician. Second, it could be that private ownership is discriminated against in the credit rating stage. If it is the latter, some of the effect of the discrimination could actually be masked by the inclusion of the firm's credit rating.

The regressions, however, suggest that controlling for a number of firm-level variables, credit ratings are not lower for private or privatized firms (Table 4). Variables with the most explanatory power of the credit rating are loan history and firm size. We find that the credit rating increases with firm size and loan history, but decreases with bad credit history (overdue loans). None of the ownership indicators are significant however. This helps rule out the concerns above, and increases our confidence that the credit rating is a good measure for a firm's credit worthiness and the ownership indicators are picking up the effect of bank discrimination.

\subsection{Loan requirements}

Discrimination against private ownership can also be tested by examining if private and privatized firms are subject to higher loan standards. Most of the literature on bank dis- 
crimination uses interest rates and loan length as indicators of discrimination in ex ante loan requirements (Blanchflower et al., 1998). In China, however, interest rates and loan length are not particularly good measures for loan standards because they are not marketdetermined. "Base" interest rates for short and long-term loans are determined by the People's Bank of China (PBC), and local bank branches only have minor discretion in adjusting actual rates above the PBC base. Loan length, on the other hand, is also set by PBC rules; a majority of loans are short-term, almost all of which are for 6 months.

China's banking sector, however, provides several unique indicators for loan requirements, including the percentage of a loan that is collateralized. There are three kinds of loans in China: guaranteed, collateralized and credit-rating-based (xinyong) loans. ${ }^{14}$ Before China issued the law on loan collateral in 1995, almost all loans were guaranteed loans, with the guarantors exclusively government agents or township enterprises. The 1995 law required more loans to be collateralized, and banks started to require borrowers to provide collateral. This law, as is true for any law in China, was not uniformly implemented, and we observe differences across localities, and firm ownership groups.

In Table 5, we analyze the determinants of loan collateral. We regress the percentage of a loan that was collatarized on our ownership dummies, and the same set of control variables as used before. The regressions for 1997 imply that the loan collateral for private (privatized) firms is 70 (40) percentage points higher than that for township enterprises in 1997 (Table 5, columns 1-3). Even in 1994, when the collateral law was first being drafted and experimented with, private firms were required to put up more collateral (columns 4-5) than the township enterprises.

In summary, we find that private and privatized firms are less likely to obtain an access to bank loans and they are subject to higher loan standards. Results from Tobit regressions on loan amounts are consistent with those of Probit regressions: private and privatized firms receive less in loans than do township enterprises. By all indications then, private and privatized firms are discriminated in China's formal loan markets. In the next two sections,

\footnotetext{
${ }^{14}$ Note that the three kinds of loans are not mutually exclusive. The bank can require both collateral and guarantees for a loan. For other loans, the credit rating may not figure in the assessment.
} 
we will investigate the consequences and the sources of discrimination.

\section{Consequences of Discrimination: Alternative Credit Sources}

RCCs and ABCs were not the only source of credit for firms. Other banks were a potential source of borrowing, as were trade credits from suppliers. Firms also borrowed directly from other firms, individuals, and non-financial institutions. The overall effect of the lending behavior of ABCs and RCCs on these firms depends on the latter's ability to access other sources of credit, and the terms on which they can borrow. In principle, these other sources of credit can offset the observed difficulty of private and privatized firms from borrowing from the ABCs and RCCs.

In Table 6, we report summary information on firms' debt structure for 1994 and 1997. Firms are once again divided into township enterprises, township enterprises that were privatized between 1994 and 1997, and private firms. We report information on total loans from $\mathrm{ABCs}$ and RCCs, loans from other banks, trade credits, and other debts. ${ }^{15}$ Overall, ABCs and RCCs were the most important source of credit for firms. In 1994, TEs (and TEs that were subsequently privatized) borrowed significantly more on average from ABCs and RCCs, and more in total, than did private firms. Private firms were, however, more likely to obtain credit through suppliers, which was the source of slightly less than half of their total credit.

Between 1994 and 1997, total credit from all sources increased for all three firms. Yet there are significant differences across these firms. For TEs, total credit increased by 16.2 percent per annum; for private firms, 18.7 percent, but for TEs that were privatized, only 8.3 percent. The key factor underlying these differences is the access to new credit from ABCs and RCCs. For TEs, credit from these two financial institutions increased by 13.8 percent; for private firms, by 6.2 percent, but for the privatized TEs, credit from the ABCs and RCCs actually declined 2.5 percent. Although the privatized TEs were able to access additional credit from other sources, the decline in credit from the ABCs and RCCs largely

\footnotetext{
${ }^{15}$ Other debts include mainly wage, tax and township fee arrears.
} 
explains their slower growth in total credit.

In Table 7, we report the results of OLS models examining the determinants of alternative sources of financing between 1994 and 1997, and the change between 1994 and 1997 conditional on information in 1994. We only report the coefficients on the ownership dummies, however, the regressions include the same set of controls as in column 3 of Table 2 . The coefficients represent the effect of being a private or privatized firm on the total amount of (change in) credit from each source in 1994 and 1997 relative to that received by a TE, controlling for differences in firm-level attributes. ${ }^{16}$ On average, private and privatized firms experienced a smaller increase in credit from the ABC and RCCs than did TEs. This was slightly reinforced by less credit from other banks. Privatized firms, however, were better able to draw on supplier credits than were TEs; for private firms, the differences are small and insignificant. Overall, access to supplier credits helped narrow the gap in access to credit for privatized firms. For private firms, however, a gap persisted, though econometrically we are not able to measure the gap with high precision.

How do we interpret these results? By all indications, private firms were not able to offset their difficulty in borrowing from the ABCs and RCCs by tapping credit from other sources. For privatized firms, on the other hand, much depends on the relative costs of borrowing from these alternative sources. If we thought that the cost of trade credits was less than or equal to that of bank borrowing, then we can argue that the discrimination in the market was negligible. Yes, these firms faced new difficulty in accessing credit from the ABCs and RCCs once they were privatized, but other firms were more than willing to fill the gap, thereby eliminating the negative effect on ownership on overall access to credit. Interviews with managers and anecdotal information, however, suggest that trade credits and bank credits were not perfect substitutes.

Trade credits are inferior to bank loans for several reasons. First, because of government regulation, the interest rate on bank loans was much lower than the market rate. Our interviews with bank mangers in 1998 show that the bank's lending rate at that time was

\footnotetext{
${ }^{16}$ The coefficients on the loans from the ABC and RCC are not comparable to those in Table 2 because we are looking at the total credit from both.
} 
about 9 percent for ABC branches and 10 percent for RCC branches, but the bank managers believed that the true market rate was 15 percent. Firms, in fact, could make money by borrowing from banks, and then lending indirectly to other firms through trade credit. As a result, it is very unlikely that these firms would prefer trade credit to bank loans. Second, trade credits were typically for much shorter periods, thereby limiting some of their usefulness. For example, a private firm could not rely on these credits for financing longterm investment. Examining our data on firm fixed capital assets (See Table A1), we observe that private and privatized firms experienced significantly smaller increases in investment between 1994 and 1997 relative to their output contribution than did TEs. In 1994, private and soon-to-be privatized TEs were the source of more than 60 percent of total firm sales, yet experienced less than 40 percent of the total increase in physical capital. And third, the firms that were in the best position to offer supplier credits were the much larger, and often, monopolistic SOEs that were able to access loans from the state-owned banks. In general, we expect firms obtaining supplier credits to have paid a premium in the form of either higher prices or interest rates on overdue balances.

\section{Sources of Discrimination}

Our findings that private or privatized firms have a lower probability of obtaining a bank loan could be due to several reasons, some of which may be interpreted as discrimination, but others that may not. We will show in this section that the differences in the probability of getting loans in China are indeed a product of discrimination that can be linked to bank incentives. To make this point, we first need to rule out a role of either informational or statistical discrimination in China's bank loan market.

\subsection{Does information matter?}

One potential reason that private ownership is less favored in the loan markets is that banks possess less information about these firms. This lack of information could be due to historical reasons or network effects (Fafchamp, 1999). Private firms did not exist when China began reforming its economy in 1978, and throughout the 1980s state banks had very limited 
experience in dealing with them.

The privatization of firms between 1994 and 1997, and bank loan data for both years enable us to examine this possibility. If information is the underlying reason for the unfavorable position of private ownership in the formal loan market, then it should be a problem only for private firms, but not for privatized firms. Since governments used to own privatized firms, banks should have experience dealing with them before they were privatized. If discrimination against privatized firms is due to the lack of information, then these firms should have been discriminated the same way before privatization. We test if privatized firms were discriminated the same way before and after privatization by comparing either the probability of privatized firms getting a bank loan or loan size in 1994 (before privatization) and 1997 (after privatization). If these same firms had the same probability of getting a loan as other township enterprises before they were privatized, but have a lower probability afterwards (or experienced a reduction in loan size subsequent to privatization), then information should not be the underlying reason for discrimination. Regressions in Table 2 show that privatized firms do not have a significantly lower probability of getting bank loans in 1994, but have a significantly lower probability of getting a bank loan in 1997. We observe a similar change with respect to loan size (Table 3 ). These results suggest that information is not the major reason behind discrimination.

\subsection{Loan default rate: statistical discrimination and joint-liability}

Banks may also be reluctant to lend to private firms because of information asymmetries for all firms. When banks do not observe the firms' true credit worthiness, they may be less willing to lend to firms of private ownership because these firms historically tended to default more on average than township enterprises. This is the case of statistical discrimination (Schwab, 1986; Arrow, 1998; Darity and Mason, 1998; Yinger, 1998). Statistical discrimination can be a rational decision of banks that find it too costly or impossible to collect detailed information on firms' credit worthiness. They use the free information at their access, namely, firm ownership, as the criterion for judging a firm's credit worthiness.

We test if discrimination is statistical by examining the ex post loan default rates of 
different ownership groups. A presumption of statistical discrimination is that private and privatized firms default more often than township enterprises. If we find otherwise, then statistical discrimination may not be the underlying reason for differential loan access. Estimating the ex post default rate also enables us to test if joint liability is a reason for discrimination. The joint liability theory (Park and Shen, 2000) predicts that township enterprises have lower default rates because these firms pool their risks. When a township enterprise is facing loan repayment difficulty, other township enterprises help the firm repay its bank loans, and thus avoid default.

Table 8 reports Probit regression results on the probability a firm had an overdue loan (a measure of default) in either 1997 or 1994, conditional on the firm having a loan in that year. Since only one private firm had an overdue loan in 1997 and none had an overdue loan in 1994, private firms drop out from the regressions. The coefficients on the privatized indicator are all negative and significant for 1997, with an magnitude of -0.12 to -0.16 . This means that, all else equal, privatized firms are 12-16 percentage points less likely to default. Privatized firms in 1994 (or the year before they were privatized), however, were equally likely to have an overdue loan as other township enterprises. These results are inconsistent with either the statistical discrimination hypothesis or the joint liability hypothesis.

\subsection{Bank's incentives}

We argue in this paper that discrimination against private firms is very likely the result of banks' incentives. Banks are willing to sacrifice profitability to lend to township enterprises because bank managers often only benefit marginally from higher bank profitability; and because they are able to enjoy perks through good relationships with local government officials that are maintained through loans to the TEs. Recall that local government officials often play an important role in bank manager selection and promotion. There are also many private benefits bank managers can enjoy by maintaining good relationship with governments. For example, local officials can use their political power to help arrange a job for bank managers' relatives, or entry into the party.

Banks' incentives, however, are heterogeneous across localities, reflecting the unevenness 
and decentralized nature of the reform process. Our theory predicts that bank mangers that have good incentive contracts care more about profitability and less about ownership itself, and therefore, to be less likely to discriminate against private firms. In addition, our theory predicts that for better-educated bank managers, all else equal, there are higher returns to lending profitably than to pursuing perks through relationships with local government officials. In other words, we expect that banks that have good incentives and/or welleducated managers are less likely to discriminate against private firms. We also expect that banks with good connections with the government enjoy more perks from lending to township enterprises, and should also discriminate more.

To examine these links, we divide the sample into two sub-samples by the medians of bank managers' attributes, including their bonus-wage ratio, the weight on profitability, education, experience, and years of residence in the township of the bank branch. The bonus-wage ratio is measured ex-ante, and tells us the size of the manager's bonus relative to their base wage if they meet all branch targets. The coefficient on profitability measures how much weight the upper level bank branch puts on profitability versus other objectives, such as deposit growth, bank security and administration, when evaluating the performance of local bank branches. We use the bank manager's years of residence in the township as a measure of their connections with the local governments. We hypothesize that bank managers with more powerful incentives, good human capital and less connections with the township will discriminate less.

In Table 9, we report the coefficients on the two ownership dummies from estimating Probit regressions for 1997 with the same set of controls as column 3 of Table 2, but separately for firms above and below the median for each firm-level attribute. Altogether, there are five pairs of estimates to compare. The results in Table 9 nicely confirm our hypothesis. All the coefficients on ownership indicators are negative and significant when using the sub-sample of firms with weak incentives or human capital, and strong connections with the township (rows 1, 3, 5, 7 and 10). For example, in localities in which the bonus-fixed wage ratio is less than the median, private and privatized firms are 85.9 percent and 37.4 percent less 
likely to receive a bank loan. In townships in which the ratio is above the median, however, private and privatized firms are as likely as comparable township enterprises to receive a loan. When profitability is given 100 percent weight in the bank's objectives, privatized firms do not appear to be discriminated against. As for private firms, although the coefficient on the ownership dummy is negative and significant, it is much smaller (in absolute value) than when less than 100 percent weight is given to profitability (-0.714 vs. -0.321).

\subsection{Omitted variable bias}

The finding that private firms are more likely to receive loans in townships in which banks have good incentives or human capital might be due to omitted variable bias. If firms of private ownership are better where banks have good incentives and human capital, then we cannot rule out the possibility that bank attributes are simply picking up unobserved differences in the quality of private and privatized firms across localities. Our grouping simply separates good private (privatized) firms from bad private (privatized) firms. If we cannot fully control for the effect of firm quality, then our estimation of ownership effects would be biased upward for the good bank attribute (high private firm quality) group and downward for the bad bank attribute (low private firm quality) group.

We use four methods to test and control for the unobserved variable bias of this sort. First, we calculate for each ownership group average performance measures and check whether private and privatized firms are systematically better in areas where banks have better attributes. Our performance measures include profit-capital ratio, profit-labor ratio, salescapital ratio and sales-labor ratio. We do not find that privatized firms are systematically better than township enterprises (results not reported in tables).

Second, we test whether privatized firms in certain localities are less likely to get bank loans before privatization. If privatized firms in localities where banks are bad are low-quality firms, then they should also be relatively less likely to get bank loans before privatization. If we fail to find that privatized firms in these localities are less likely to get loans preprivatization, then their post-privatization lower probability of getting a bank loan could be due to discrimination against private ownership. To implement this idea, we divide 
the 1994 sample of firms by 1997 bank attributes, and estimate for the two sub-samples (above and below the median) the effect of being privatized on the probability of credit access. The dependent variable is an indicator, which equals 1 if the firm has a loan in 1994, and 0 otherwise. The independent variables are the same as column 3 in Table 2. Regression results show that privatized firms in the "good bank" attributes' groups do not systematically get more loans before privatization, since none of the coefficients on privatized firms are significantly negative (Table 10, column 1). This indicates that privatized firms are not systematically more credit-worthy in the good bank attributes' groups.

Third, we employ firm fixed-effect estimation. Specifically, we use the first difference of all variables that vary across years and examine whether the change of ownership affects the change of loan in localities of different bank attributes. Assuming that unobserved firm quality does not vary across years, the firm fixed-effect model will eliminate these factors and provide unbiased estimations. Private firms will drop out of the sample in the fixed-effect model, since their ownership does not change over time. The dependent variable of the fixed effect model is an indicator, which equals 1 if the firm has a loan increase between 1994 and 1997, and 0 otherwise. The independent variables include the change of manager's education and age and a privatization indicator. The regression results of the fixed effect model confirm our earlier findings that banks with managers who have weak incentives, less education and experience, and strong connections with the township, are more likely to discriminate (Table 10, column 2).

The firm fixed-effect model may not completely correct the omitted variable bias however. If the change of ownership is correlated with bank attributes, then the change of ownership itself is endogenous. In other words, it could be that good firms are privatized in localities where banks have good incentives, while bad firms are privatized in localities where banks have poor incentives. In this case, bank attributes are simply picking up the quality of privatized firms (relative to township enterprises in each group) in different localities.

Finally, we test directly whether ownership change is the result of the interaction between firm quality and bank attributes by applying a Probit model to estimate the probability 
of privatization. The right hand size variables are firm attributes, bank attributes and interactions of bank and firm attributes. If the interaction terms are not significant, then we can reject the hypothesis that good firms are privatized in localities where banks are good, while bad firms are privatized where banks are bad. Regressions show that the interaction terms are not significant (not shown in tables).

To summarize, our empirical exercises show that bank discrimination decreases with bank managers' incentives, human capitals, and increases with their connections with local governments. The results are robust to various ways of correcting omitted variable bias.

\section{Conclusions}

In this paper, we analyze commercial bank lending behavior in rural China. By all indications, private and privatized firms have been discriminated against in the formal loan market. This discrimination is not uniform across our sample, however, and is systematically correlated with bank manager's incentives and human capital: banks discriminate less when bank managers have good incentives and human capital.

The discrimination that persists has important real consequences for the Chinese economy as bank credits do not go to the most profitable projects, and the most efficient firms have to incur higher costs in order to expand. In both the short- and long-run, this will affect individual firm growth through access to working capital and through its effect on firms' fixed investment. Discrimination against private firms also adversely affects the "bottom line" of China's commercial banks, and their ability to deal with a legacy of non-performing loans.

From both perspectives, our analysis highlights the need for continued reform of governance structures in China's financial sector, and the local political economy that shapes them.

\section{Appendix}

PROOF of PROPOSITION 1: 
If no PEs are being financed, the problem is trivial, and so we will consider the case when there are PEs being financed. Define $\beta_{2}$ as the type of the marginal TE, and $\beta_{1}$ as the type of the marginal PE. Since it must be true that the bank is indifferent between lending to the two ownership types at the margin, then $U_{1}\left(e_{1}^{*}\right)-U_{2}\left(e_{2}^{*}\right)=0$, where $U_{2}\left(e_{2}^{*}\right)=a\left(\beta_{2} e_{2}^{*} r-\right.$ 1) $-C\left(e_{2}^{*}\right) / b+L$, and $U_{1}\left(e_{1}^{*}\right)=a\left(\beta_{1} e_{1}^{*} r-1\right)-C\left(e_{1}^{*}\right) / b$. Since $\partial U\left(e^{*}\right) / \partial \beta>0$, it follows that $\beta_{2}<\beta_{1}$.

\section{PROOF OF PROPOSITION 2:}

Again, we use the maximized utility function to conduct comparative statics. Totally differentiating the maximized utility functions with respect to a, we obtain $\partial U_{2}^{*} / \partial a=\beta_{2} e_{2}^{*} r-1$, and $\partial U_{1}^{*} / \partial a=\beta_{1} e_{1}^{*} r-1$. Since $\beta_{1}>\beta_{2}$, and $\partial e / \partial \beta>0$, we know $e_{1}^{*}>e_{2}^{*}$. This implies that $\partial U_{1}^{*} / \partial a>\partial U_{2}^{*} / \partial a$. So, at the old margin, lending to a PE is more profitable than to a TE. But, we know that the bank has to be indifferent between the two ownership types at the margin, and so the profit type has to be lower than before for the marginal PE, and higher for the marginal TE. Algebraically, $\beta_{1}^{\prime}<\beta_{1}$ and $\beta_{2}^{\prime}>\beta_{2}$. Since there is still discrimination in equilibrium, it has to be true that $\beta_{2}<\beta_{2}^{\prime}<\beta_{1}^{\prime}<\beta_{1}$. This means that the old borrowing TEs in the profit range $\left[\beta_{2}, \beta_{2}\right]$ are replaced by the new borrowing PEs in the profit range $\left[\beta_{1}^{\prime}, \beta_{1}\right]$, thus the average profitability of the bank improves.

The proofs for the effect of changes of $b$ and $L$ are similar, and are skipped here. Q.E.D. 


\section{References}

Arrow, Kenneth, "What Has Economics to Say about Racial Discrimination," Journal of Economic Perspectives, Spring 1998, 12(2), pp. 91-100.

Becker, Gary, The Economics of Discrimination, Chicago: University of Chicago Press, 1957.

Becker, Gary, The Evidence Against Banks Doesn't Prove Bias,” Business Week, April 19, 1993, pp. 18.

Blanchflower, David, Phillip Levine and David Zimmerman, "Discrimination in the Small Business Credit Market," NBER Working Paper, 1998.

Brandt, Loren and Xiaodong Zhu, "What Ails China: A Long-run Perspective on Growth and Inflation (and Deflation) in China", in East Asia post-crisis: Continuity and Change, ed. Wendy Dobson and Edward Safarian, University of Toronto Press, 2002.

Brandt, Loren and Xiaodong Zhu, "Redistribution in a Decentralizing Economy: Growth and Inflation in Reform China, Journal of Political Economy, April 2000, 108(21), pp. 422-439.

Brainard, Lawrence, "Strategies for economic transformation in Central and Eastern Europe: The Role of Financial Market Reform," in Blommenstein, Hans and Marrese, Michael (eds), Transformation of Planned Economies: Property Rights Reform and Macroeconomic Stability, Paris, OECD, 1991.

Cao, Yuanzheng, Yingyi Qian, and Barry Weingast, "From Federalism, Chinese Style, to Privatization, Chinese Style." Economics of Transition, 1999, 7(1), pp. 103-31.

Che, Jiahua, and Yingyi Qian, "Insecure Property Rights and Government Ownership of Firms," Quarterly Journal of Economics, May 1998.

Chen, Hongyi and Scott Rozelle, "Leaders, Managers, and the Organization of Township and Village Enterprises in China," Journal of Development Economics, December 1999, 60(2), pp. 529-57.

China Statistical Yearbook 1978-2000, Beijing: China Statistical Press.

Darity, William and Patrick Mason, "Evidence on Discrimination in Employment: Codes of Color, Codes of Gender," Journal of Economic Perspectives, Spring 1998, 12(2), pp. 63-90.

Fafchamps, Marcel, "Ethnicity and Credit in African Manufacturing," Journal of Development Economics, 2000, v61, pp. 205-235.

Heckman, James, "Detecting Discrimination," Journal of Economic Perspectives, Spring 1998, 12(2), pp. 101-116. 
Lardy, Nicholas, "When Will China's Financial System Meet China's Needs?" Conference on Policy Reform in China, Stanford University, 1999.

Ladd, Helen, "Evidence on Discrimination in Mortgage Lending," Journal of Economic Perspectives, Spring 1998, 12(2), pp. 41-62.

Loury, Glenn, "Discrimination in the Post-Civil Rights Era: Beyond Market Interactions," Journal of Economic Perspectives, Spring 1998, 12(2), pp. 117-126.

Munnell, Alicia, Geoffrey Tootell, Lynn Browne and James McEneaney, "Mortgage Lending in Boston: Interpreting HMDA Data" American Economics Review, March 1996, 86(1), pp. 25-53.

Neal, Derek, and William Johnson, "The Role of Premarket Factors in Black-White Wage Differences," Journal of Political Economy, 1996, 104(5), pp. 869-895.

Nyberg, Albert and Scott Rozelle, "Accelerating Development in Rural China," Wold Bank, Washington DC, 1999.

Park, Albert, Loren Brandt and John Giles, "Giving Credit where Credit is

Due: The Changing Role of Rural Financial Institutions in China", mimeo, 1997.

Schwab, Stewart, "Is Statistical Discrimination Efficient," American Economics Review, March 1986, 76(1), pp. 228-234.

Simon, Johnson, John McMillan and Christopher Woodruff, "Courts and Relational Contracts," Journal of Law, Economics and Organization, 18(1), Spring 2002, pp. 221-277.

Simon, Johnson, John McMillan and Christopher Woodruff, "Property Rights and Finance," NBER Working Paper, 2002.

World Bank, "China's Emerging Private Enterprises: Prospects for the New Century," International Finance Corporation, 2000.

Yinger, John, "Measuring Racial Discrimination with Fair Housing Audits: Caught in the Act," American Economics Review, December 1986, 76(5), pp. 881-893.

Yinger, John, "Evidence on Discrimination in Consumer Markets," Journal of Economic Perspectives, Spring 1998, 12(2), pp. 63-90.

Zhang, Houyi and Lizhi Ming, Report on the Development of Private Enterprises in China, Social Sciences Documentation Press, 2001. 
Table 1: Firm Loans from Rural Credit Cooperative (RCC) and Agricultural Bank of China (ABC)

\begin{tabular}{|c|c|c|c|c|}
\hline & \multicolumn{3}{|c|}{ Ownership } & \multirow[b]{2}{*}{ Total } \\
\hline & $\mathrm{TE}$ & Privatized TE & Private & \\
\hline Number of observations & 39 & 81 & 32 & 152 \\
\hline \multicolumn{5}{|l|}{ Loan from $\mathrm{ABC}$ and $\mathrm{RCC}$ in 1994} \\
\hline 1 Percentage of firms with & & & & \\
\hline no loan & 18 & 20 & 56 & 27 \\
\hline One loan from $\mathrm{RCC}$ or $\mathrm{ABC}$ & 51 & 44 & 38 & 45 \\
\hline Loans from both $\mathrm{RCC}$ and $\mathrm{ABC}$ & 31 & 36 & 6 & 28 \\
\hline 2 Average amount of loan (million yuan) & $\begin{array}{c}2.08 \\
(3.56)\end{array}$ & $\begin{array}{l}1.45 \\
(2.32)\end{array}$ & $\begin{array}{c}0.43 \\
(1.07)\end{array}$ & $\begin{array}{c}1.40 \\
(2.57)\end{array}$ \\
\hline $\begin{array}{l}3 \text { Average amount of loan conditional on having } \\
\text { loan in at least one year (million yuan) }\end{array}$ & $\begin{array}{c}2.32 \\
(3.68)\end{array}$ & $\begin{array}{l}1.63 \\
(2.40)\end{array}$ & $\begin{array}{c}0.72 \\
(1.32)\end{array}$ & $\begin{array}{c}1.69 \\
(2.73)\end{array}$ \\
\hline \multicolumn{5}{|l|}{$\underline{\text { Loan from } \mathrm{ABC} \text { and } \mathrm{RCC} \text { in } 1997}$} \\
\hline $\begin{array}{l}4 \text { Percentage of firms with } \\
\text { no loan }\end{array}$ & 13 & 19 & 50 & 24 \\
\hline One loan from $\mathrm{RCC}$ or $\mathrm{ABC}$ & 36 & 49 & 41 & 44 \\
\hline Loans from both RCC and $\mathrm{ABC}$ & 51 & 32 & 9 & 32 \\
\hline 5 Average amount of loan (million yuan) & $\begin{array}{c}3.12 \\
(4.13)\end{array}$ & $\begin{array}{c}1.51 \\
(1.98)\end{array}$ & $\begin{array}{c}0.64 \\
(1.44)\end{array}$ & $\begin{array}{c}1.74 \\
(2.75)\end{array}$ \\
\hline $\begin{array}{l}6 \text { Average amount of loan conditional on having } \\
\text { loan in at least one year (million yuan) }\end{array}$ & $\begin{array}{c}3.48 \\
(4.22)\end{array}$ & $\begin{array}{l}1.70 \\
(2.02)\end{array}$ & $\begin{array}{c}1.07 \\
(1.75)\end{array}$ & $\begin{array}{c}2.10 \\
(2.90)\end{array}$ \\
\hline
\end{tabular}


Table 2: Probit Regressions Examining the Determinants of Having a Bank Loan in 1997 or 1994 Conditional on Firms Demanding a Loan (Dependent variable: no bank loan $=0$, have a bank loan $=1$ )

\begin{tabular}{|c|c|c|c|c|c|c|c|}
\hline & (1) & (2) & (3) & (4) & (5) & (6) & (7) \\
\hline $\begin{array}{l}\text { Independent variables } \\
(\mathrm{dF} / \mathrm{dx})\end{array}$ & 1997 & 1997 & 1997 & 1997 & 1994 & 1994 & 1994 \\
\hline \multicolumn{8}{|l|}{ Ownership Indicators } \\
\hline Private & $\begin{array}{c}-0.382 * * * \\
(-3.32)\end{array}$ & $\begin{array}{c}-0.544 * * * \\
(-3.99)\end{array}$ & $\begin{array}{c}-0.514 * * * \\
(-3.67)\end{array}$ & $\begin{array}{c}-0.491 * * * \\
(-3.28)\end{array}$ & $\begin{array}{c}-0.409 * * * \\
(-3.21)\end{array}$ & $\begin{array}{c}-0.650 * * * \\
(-3.71)\end{array}$ & $\begin{array}{c}-0.632 * * * \\
(-3.56)\end{array}$ \\
\hline $\begin{array}{l}\text { Privatized } \\
\text { (between 94-97) }\end{array}$ & $\begin{array}{c}-0.201 * * * \\
(-2.56)\end{array}$ & $\begin{array}{c}-0.212 * * * \\
(-2.68)\end{array}$ & $\begin{array}{c}-0.199 * * \\
(-2.48)\end{array}$ & $\begin{array}{c}-0.176^{* *} \\
(-2.03)\end{array}$ & $\begin{array}{l}-0.018 \\
(-0.21)\end{array}$ & $\begin{array}{l}-0.027 \\
(-0.31)\end{array}$ & $\begin{array}{l}-0.004 \\
(-0.04)\end{array}$ \\
\hline \multicolumn{8}{|l|}{ Credit Worthiness } \\
\hline Credit rating & & & $\begin{array}{l}0.051 * * * \\
(2.94)\end{array}$ & $\begin{array}{c}0.046^{* * *} \\
(2.61)\end{array}$ & & & $\begin{array}{c}0.036^{*} \\
(1.95)\end{array}$ \\
\hline $\begin{array}{l}\text { Firm manager's } \\
\text { education }\end{array}$ & & $\begin{array}{l}0.031^{*} \\
(1.73)\end{array}$ & $\begin{array}{l}0.026 \\
(1.42)\end{array}$ & $\begin{array}{l}0.020 \\
(1.10)\end{array}$ & & $\begin{array}{l}-0.002 \\
(-0.08)\end{array}$ & $\begin{array}{l}-0.008 \\
(-0.43)\end{array}$ \\
\hline Firm manager's age & & $\begin{array}{l}-0.004 \\
(-0.67)\end{array}$ & $\begin{array}{l}-0.002 \\
(-0.43)\end{array}$ & $\begin{array}{l}-0.003 \\
(-0.56)\end{array}$ & & $\begin{array}{l}0.002 \\
(0.48)\end{array}$ & $\begin{array}{l}0.003 \\
(0.59)\end{array}$ \\
\hline $\begin{array}{l}\text { Firm's age }(=1 \text { if } \\
\text { established after } 1990)\end{array}$ & & $\begin{array}{c}0.222 * * \\
(2.20)\end{array}$ & $\begin{array}{c}0.204^{* * *} \\
(2.00)\end{array}$ & $\begin{array}{l}0.193^{*} \\
(1.81)\end{array}$ & & $\begin{array}{c}0.367 * * \\
(2.43)\end{array}$ & $\begin{array}{c}0.361^{* *} \\
(2.43)\end{array}$ \\
\hline Sales (lagged) & & & & $\begin{array}{l}0.002 \\
(1.17)\end{array}$ & & & \\
\hline $\begin{array}{l}\text { Debt asset ratio } \\
\text { (lagged) }\end{array}$ & & & & $\begin{array}{l}-0.079 \\
(-0.69)\end{array}$ & & & \\
\hline $\begin{array}{l}\text { Capital labor ratio } \\
\text { (lagged) }\end{array}$ & & & & $\begin{array}{l}0.0005 \\
(0.09)\end{array}$ & & & \\
\hline \multicolumn{8}{|l|}{ Other Control Variables } \\
\hline $\begin{array}{l}\text { Bank type } \quad(\mathrm{RCC}=0, \\
\mathrm{ABC}=1)\end{array}$ & $\begin{array}{l}-0.116^{*} \\
(-1.82)\end{array}$ & $\begin{array}{l}-0.119 \\
(-1.84)\end{array}$ & $\begin{array}{l}-0.092 \\
(-1.38)\end{array}$ & $\begin{array}{l}-0.096 \\
(-1.45)\end{array}$ & $\begin{array}{c}-0.162 * * \\
(-2.36)\end{array}$ & $\begin{array}{c}-0.160 * * \\
(-2.30)\end{array}$ & $\begin{array}{l}-0.137^{*} \\
(-1.93)\end{array}$ \\
\hline Province (Zhejiang=1) & $\begin{array}{l}-0.072 \\
(-1.03)\end{array}$ & $\begin{array}{l}-0.062 \\
(-0.80)\end{array}$ & $\begin{array}{l}-0.072 \\
(-0.91)\end{array}$ & $\begin{array}{l}-0.072 \\
(-0.90)\end{array}$ & $\begin{array}{l}-0.060 \\
(-0.81)\end{array}$ & $\begin{array}{l}-0.070 \\
(-0.88)\end{array}$ & $\begin{array}{l}-0.082 \\
(-1.02)\end{array}$ \\
\hline Observation & 238 & 238 & 238 & 238 & 216 & 216 & 216 \\
\hline Pseudo R-squared & 0.09 & 0.12 & 0.15 & 0.15 & 0.13 & 0.13 & 0.14 \\
\hline
\end{tabular}

Notes:

1. Coefficients are $\mathrm{dF} / \mathrm{dx}$. Numbers in parentheses are t-ratios. Significance level $0.1,0.05$ and 0.01 are noted by *, **, and $* * *$. Industry dummies are not shown. 
Table 3: Tobit Regressions Examining the Determinants of Loan Amount in 1997 or 1994 Conditional on Firms Demanding a Loan (left censored at zero)

\begin{tabular}{|c|c|c|c|c|c|c|c|}
\hline & (1) & (2) & (3) & (4) & (5) & (6) & (7) \\
\hline $\begin{array}{l}\text { Independent variables } \\
(\mathrm{dF} / \mathrm{dx})\end{array}$ & 1997 & 1997 & 1997 & 1997 & 1994 & 1994 & 1994 \\
\hline \multicolumn{8}{|l|}{ Ownership } \\
\hline \multicolumn{8}{|l|}{ Indicators } \\
\hline Private & $\begin{array}{c}-605.3 * * * \\
(-5.33)\end{array}$ & $\begin{array}{c}-652.2 * * * \\
(-5.16)\end{array}$ & $\begin{array}{c}-641.2 * * * \\
(-5.04)\end{array}$ & $\begin{array}{c}-466.3 * * * \\
(-3.70)\end{array}$ & $\begin{array}{c}-340.7 * * * \\
(-3.58)\end{array}$ & $\begin{array}{c}-256.2 * * \\
(-2.24)\end{array}$ & $\begin{array}{c}-252.9 * * \\
(-2.20)\end{array}$ \\
\hline $\begin{array}{l}\text { Privatized } \\
\text { (between 94-97) }\end{array}$ & $\begin{array}{c}-330.4 * * * \\
(-4.37)\end{array}$ & $\begin{array}{c}-341.9 * * * \\
(-4.69)\end{array}$ & $\begin{array}{c}-336.7 * * * \\
(-4.61)\end{array}$ & $\begin{array}{c}-219.8 * * * \\
(-3.03)\end{array}$ & $\begin{array}{l}-68.0 \\
(-1.11)\end{array}$ & $\begin{array}{l}-65.9 \\
(-1.08)\end{array}$ & $\begin{array}{l}-63.6 \\
(-1.03)\end{array}$ \\
\hline \multicolumn{8}{|l|}{ Credit Worthiness } \\
\hline Credit rating & & & $\begin{array}{l}13.1 \\
(0.81)\end{array}$ & $\begin{array}{l}-6.72 \\
(-0.44)\end{array}$ & & & $\begin{array}{c}5.1 \\
(0.38)\end{array}$ \\
\hline Firm manager's & & $42.7 * *$ & $40.8 * *$ & 21.4 & & -3.1 & -4.1 \\
\hline education & & $(2.55)$ & $(2.42)$ & $(1.34)$ & & $(-0.24)$ & $(-0.31)$ \\
\hline Firm manager's age & & $\begin{array}{l}-8.6^{*} \\
(-1.78)\end{array}$ & $\begin{array}{l}-8.4^{*} \\
(-1.75)\end{array}$ & $\begin{array}{c}-13.3 * * * \\
(-2.96)\end{array}$ & & $\begin{array}{l}-1.8 \\
(-0.59)\end{array}$ & $\begin{array}{l}-1.8 \\
(-0.58)\end{array}$ \\
\hline $\begin{array}{l}\text { Firm's age }(=1 \text { if } \\
\text { est. after 1990) }\end{array}$ & & $\begin{array}{c}13.4 \\
(0.14)\end{array}$ & $\begin{array}{l}9.63 \\
(0.10)\end{array}$ & $\begin{array}{l}-113.2 \\
(-1.17)\end{array}$ & & $\begin{array}{l}-123.7 \\
(-1.35)\end{array}$ & $\begin{array}{l}-123.0 \\
(-1.34)\end{array}$ \\
\hline Sales (lagged) & & & & $\begin{array}{l}3.7 * * * \\
(5.35)\end{array}$ & & & \\
\hline Debt asset ratio & & & & $-386.4 * * *$ & & & \\
\hline (lagged) & & & & $(-3.73)$ & & & \\
\hline $\begin{array}{l}\text { Capital labor ratio } \\
\text { (lagged) }\end{array}$ & & & & $\begin{array}{c}-0.9 \\
(-0.33)\end{array}$ & & & \\
\hline \multicolumn{8}{|c|}{ Other Control Variables } \\
\hline $\begin{array}{l}\text { Bank type }(\mathrm{RCC}=0 \text {, } \\
\mathrm{ABC}=1)\end{array}$ & $\begin{array}{l}-12.4 \\
(-0.20)\end{array}$ & $\begin{array}{c}-5.6 \\
(-0.09)\end{array}$ & $\begin{array}{c}1.1 \\
(0.02)\end{array}$ & $\begin{array}{l}-12.8 \\
(-0.23)\end{array}$ & $\begin{array}{l}-2.6 \\
(-1.11)\end{array}$ & $\begin{array}{c}-3.5 \\
(-0.07)\end{array}$ & $\begin{array}{c}1.1 \\
(0.02)\end{array}$ \\
\hline Province & 86.47 & 114.4 & 110.5 & 113.0 & 26.7 & 25.8 & 110.5 \\
\hline (Zhejiang=1) & $(1.24)$ & $(1.55)$ & $(1.50)$ & $(1.62)$ & $(0.49)$ & $(0.45)$ & $(1.50)$ \\
\hline Observation & 238 & 238 & 238 & 238 & 216 & 216 & 216 \\
\hline Pseudo R-squared & 0.02 & 0.04 & 0.03 & 0.04 & 0.01 & 0.01 & 0.14 \\
\hline
\end{tabular}

Notes:

1. Numbers in parentheses are t-ratios. Significance level $0.1,0.05$ and 0.01 are noted by $*, * *$, and $* * *$. Industry dummies are not shown. 
Table 4: OLS Regressions Examining the Determinants of Credit Ratings in 1997

Independent variables $\quad$ Dependent variable: credit ratings in 1997

\begin{tabular}{|c|c|c|c|c|}
\hline & $(1)$ & $(2)$ & (3) & (4) \\
\hline \multicolumn{5}{|l|}{ Ownership Indicators } \\
\hline Private & $\begin{array}{c}-0.28 \\
(-0.70)\end{array}$ & $\begin{array}{c}-0.31 \\
(-0.70)\end{array}$ & $\begin{array}{c}-0.18 \\
(-0.42)\end{array}$ & $\begin{array}{c}-0.14 \\
(-0.34)\end{array}$ \\
\hline Privatized (between 94-97) & $\begin{array}{l}-0.33 \\
(-1.13)\end{array}$ & $\begin{array}{c}-0.33 \\
(-1.14)\end{array}$ & $\begin{array}{l}-0.12 \\
(-0.42)\end{array}$ & $\begin{array}{l}-0.24 \\
(-0.86)\end{array}$ \\
\hline \multicolumn{5}{|l|}{ Loan History } \\
\hline $\begin{array}{l}\text { Loan } 94(=1 \text { if there is a loan } \\
\text { in } 1994) \\
\text { Overdue ( } 1=\text { if an overdue loan } \\
\text { in history }\end{array}$ & & & & $\begin{array}{l}0.67 * * * \\
(2.88) \\
-1.02 * * \\
(2.73)\end{array}$ \\
\hline \multicolumn{5}{|l|}{ Credit Worthiness } \\
\hline Firm manager's Education & & $\begin{array}{l}0.11 * \\
(1.78)\end{array}$ & $\begin{array}{c}0.06 \\
(0.96)\end{array}$ & $\begin{array}{c}0.07 \\
(1.09)\end{array}$ \\
\hline Firm manager's age & & $\begin{array}{l}-0.02 \\
(-1.40)\end{array}$ & $\begin{array}{l}-0.03 * \\
(-1.94)\end{array}$ & $\begin{array}{l}-0.04 * * \\
(-2.18)\end{array}$ \\
\hline $\begin{array}{l}\text { Firm's age ( }=1 \text { if established } \\
\text { after 1990) }\end{array}$ & & $\begin{array}{l}-0.06 \\
(-0.16)\end{array}$ & $\begin{array}{c}-0.07 \\
(-0.21)\end{array}$ & $\begin{array}{l}-0.09 \\
(-0.25)\end{array}$ \\
\hline Sales (lagged) & & & $\begin{array}{l}0.024 * * * \\
(5.37)\end{array}$ & $\begin{array}{l}0.022 * * * \\
\quad(4.93)\end{array}$ \\
\hline Debt asset ratio (lagged) & & & $\begin{array}{c}-0.17 \\
(-0.44)\end{array}$ & $\begin{array}{c}-0.13 \\
(-0.34)\end{array}$ \\
\hline Capital labor ratio (lagged) & & & $\begin{array}{l}2.15^{*} \\
(1.83)\end{array}$ & $\begin{array}{l}2.18^{*} \\
(1.89)\end{array}$ \\
\hline \multicolumn{5}{|l|}{ Other Control Variables } \\
\hline Bank type $(\mathrm{RCC}=0, \mathrm{ABC}=1)$ & $\begin{array}{l}-0.45 * \\
(1.89)\end{array}$ & $\begin{array}{l}-0.44 * \\
(-1.88)\end{array}$ & $\begin{array}{l}-0.38 * \\
(-1.76)\end{array}$ & $\begin{array}{l}-0.27 \\
(-1.22)\end{array}$ \\
\hline Province (Zhejiang=1) & $\begin{array}{l}-0.01 \\
(-0.04)\end{array}$ & $\begin{array}{l}-0.075 \\
(-0.27)\end{array}$ & $\begin{array}{l}0.150 \\
(0.57)\end{array}$ & $\begin{array}{l}0.005 \\
(0.02)\end{array}$ \\
\hline Observation & 281 & 281 & 281 & 281 \\
\hline Adjusted R-squared & 0.00 & 0.01 & 0.14 & 0.17 \\
\hline
\end{tabular}

Notes:

1. Numbers in parentheses are t-ratios. Significance level $0.1,0.05$ and 0.01 are noted by $* * *$, and $* * *$. Industry dummies are not shown. 
Table 5: OLS Regressions Examining the Determinants of Loan Collateral

\begin{tabular}{|c|c|c|c|c|c|}
\hline \multirow[b]{3}{*}{ Independent variables } & \multicolumn{5}{|c|}{ Dependent Variable: \% loan collateralized } \\
\hline & \multicolumn{3}{|c|}{1997} & \multicolumn{2}{|c|}{1994} \\
\hline & (1) & (2) & (3) & (4) & (5) \\
\hline \multicolumn{6}{|l|}{ Ownership Indicators } \\
\hline Private & $\begin{array}{c}85.90 * * * \\
(6.34)\end{array}$ & $\begin{array}{c}74.83 * * * \\
(4.83)\end{array}$ & $\begin{array}{c}67.14^{* * * *} \\
(3.72)\end{array}$ & $\begin{array}{l}25.11 * \\
(1.81)\end{array}$ & $\begin{array}{c}33.44 * * \\
(2.03)\end{array}$ \\
\hline Privatized (between 94-97) & $\begin{array}{c}48.00 * * * \\
(5.68)\end{array}$ & $\begin{array}{c}47.79 * * * \\
(5.59)\end{array}$ & $\begin{array}{c}43.94 * * * \\
(4.23)\end{array}$ & $\begin{array}{l}9.25 \\
(1.12)\end{array}$ & $\begin{array}{l}13.25 \\
(1.41)\end{array}$ \\
\hline \multicolumn{6}{|l|}{ Credit Worthiness } \\
\hline Credit rating & & $\begin{array}{c}-1.01 \\
(-0.52)\end{array}$ & $\begin{array}{c}0.07 \\
(0.03)\end{array}$ & & \\
\hline Firm manager's Education & & $\begin{array}{c}2.07 \\
(1.07)\end{array}$ & $\begin{array}{c}2.10 \\
(0.97)\end{array}$ & & $\begin{array}{c}-2.62 \\
(-1.22)\end{array}$ \\
\hline Firm manager's age & & $\begin{array}{c}0.13 \\
(0.25)\end{array}$ & $\begin{array}{c}0.05 \\
(0.08)\end{array}$ & & $\begin{array}{c}-0.17 \\
(-0.31)\end{array}$ \\
\hline $\begin{array}{l}\text { Firm's age }(=1 \text { if established } \\
\text { after 1990) }\end{array}$ & & $\begin{array}{l}15.28 \\
(1.40)\end{array}$ & $\begin{array}{l}17.49 \\
(1.31)\end{array}$ & & $\begin{array}{l}5.39 \\
(0.44)\end{array}$ \\
\hline Sales (lagged) & & & $\begin{array}{c}-0.12 \\
(-1.56)\end{array}$ & & \\
\hline Debt asset ratio (lagged) & & & $\begin{array}{c}-5.79 \\
(-0.44)\end{array}$ & & \\
\hline Capital labor ratio (lagged) & & & $\begin{array}{c}-0.38 \\
(-0.94)\end{array}$ & & \\
\hline \multicolumn{6}{|l|}{ Other Control Variables } \\
\hline Bank type $(\mathrm{RCC}=0, \mathrm{ABC}=1)$ & $\begin{array}{c}-2.69 \\
(-0.39)\end{array}$ & $\begin{array}{c}-2.73 \\
(-0.39)\end{array}$ & $\begin{array}{c}-1.89 \\
(-0.24)\end{array}$ & $\begin{array}{c}0.89 \\
(0.12)\end{array}$ & $\begin{array}{c}1.88 \\
(0.23)\end{array}$ \\
\hline Province (Zhejiang=1) & $\begin{array}{l}-5.26 \\
(-0.69)\end{array}$ & $\begin{array}{c}-2.18 \\
(-0.26)\end{array}$ & $\begin{array}{c}1.51 \\
(0.07)\end{array}$ & $\begin{array}{c}-28.21 * * * \\
(-3.60)\end{array}$ & $\begin{array}{c}-37.28 * * * \\
(-3.87)\end{array}$ \\
\hline Observation & 144 & 144 & 144 & 141 & 123 \\
\hline Adj. R-squared & 0.27 & 0.26 & 0.23 & 0.08 & 0.08 \\
\hline
\end{tabular}

Notes:

1. Numbers in parentheses are t-ratios. Coefficients are $\mathrm{dF} / \mathrm{dx}$. Significance level $0.1,0.05$ and 0.01 are noted by $*$, $* *$, and $* * *$. Industry dummies are not shown. 
William Davidson Institute Working Paper 517

Table 6: Firm's Debt Structure: Mean and Standard Deviation (million yuan)

\begin{tabular}{|c|c|c|c|c|c|c|}
\hline & \multicolumn{3}{|c|}{1994} & \multicolumn{3}{|c|}{1997} \\
\hline & TE & $\begin{array}{c}\text { Privatized } \\
1994-97\end{array}$ & Private & $\mathrm{TE}$ & $\begin{array}{c}\text { Privatized } \\
1994-97\end{array}$ & Private \\
\hline Number of observations & 36 & 69 & 24 & 36 & 69 & 24 \\
\hline \multicolumn{7}{|l|}{ Debts } \\
\hline Loan from $A B C \& R C C$ & $\begin{array}{c}2.23 \\
(3.66)\end{array}$ & $\begin{array}{c}1.59 \\
(2.43)\end{array}$ & $\begin{array}{c}0.56 \\
(1.22)\end{array}$ & $\begin{array}{c}3.29 \\
(4.25)\end{array}$ & $\begin{array}{c}1.47 \\
(1.79)\end{array}$ & $\begin{array}{c}0.67 \\
(1.47)\end{array}$ \\
\hline Loan from other banks & $\begin{array}{c}0.22 \\
(0.89)\end{array}$ & $\begin{array}{c}0.87 \\
(3.54)\end{array}$ & $\begin{array}{c}0.22 \\
(0.88)\end{array}$ & $\begin{array}{c}0.89 \\
(3.78)\end{array}$ & $\begin{array}{c}1.18 \\
(4.25)\end{array}$ & $\begin{array}{c}0.62 \\
(1.30)\end{array}$ \\
\hline Trade credit received & $\begin{array}{c}1.61 \\
(2.97)\end{array}$ & $\begin{array}{c}1.10 \\
(1.59)\end{array}$ & $\begin{array}{c}0.80 \\
(1.21)\end{array}$ & $\begin{array}{c}1.64 \\
(2.97)\end{array}$ & $\begin{array}{c}1.81 \\
(2.82)\end{array}$ & $\begin{array}{c}0.91 \\
(1.34)\end{array}$ \\
\hline Other debt & $\begin{array}{l}1.70 \\
(2.96)\end{array}$ & $\begin{array}{c}0.82 \\
(1.04)\end{array}$ & $\begin{array}{c}0.40 \\
(0.89)\end{array}$ & $\begin{array}{c}3.21 \\
(7.68)\end{array}$ & $\begin{array}{c}1.11 \\
(1.51)\end{array}$ & $\begin{array}{c}0.87 \\
(1.91)\end{array}$ \\
\hline Total & $\begin{array}{c}5.76 \\
(7.17)\end{array}$ & $\begin{array}{c}4.38 \\
(6.08)\end{array}$ & $\begin{array}{c}1.84 \\
(3.20)\end{array}$ & $\begin{array}{c}9.03 \\
(12.94)\end{array}$ & $\begin{array}{c}5.56 \\
(8.02)\end{array}$ & $\begin{array}{c}3.08 \\
(4.39)\end{array}$ \\
\hline
\end{tabular}


Table 7: Coefficients (t-ratios) of Ownership Indicators of OLS Models Examining the Determinants of Amount of Alternative Finance Sources

\begin{tabular}{|c|c|c|c|}
\hline Specifications & Private & $\begin{array}{c}\text { Privatized } \\
\text { (between 94-97) }\end{array}$ & Sample size \\
\hline \multicolumn{4}{|l|}{ Amount in 1994} \\
\hline Total loan from $\mathrm{ABC}$ and $\mathrm{RCC}$ & $\begin{array}{l}-184.2^{*} \\
(-1.49)\end{array}$ & $\begin{array}{l}-60.8 \\
(-0.78)\end{array}$ & 119 \\
\hline Total loan from all banks & $\begin{array}{l}-176.1 \\
(-1.07)\end{array}$ & $\begin{array}{l}16.6 \\
(0.16)\end{array}$ & 119 \\
\hline Trade credit received & $\begin{array}{l}-52.1 \\
(-0.44)\end{array}$ & $\begin{array}{c}27.1 \\
(0.36)\end{array}$ & 119 \\
\hline Other credit & $\begin{array}{l}-65.7 \\
(-0.78)\end{array}$ & $\begin{array}{l}-22.3 \\
(-0.42)\end{array}$ & 119 \\
\hline Total firm debt & $\begin{array}{l}-293.9 \\
(-0.99)\end{array}$ & $\begin{array}{l}21.4 \\
(0.12)\end{array}$ & 119 \\
\hline \multicolumn{4}{|l|}{ Amount in 1997} \\
\hline Total loan from $\mathrm{ABC}$ and $\mathrm{RCC}$ & $\begin{array}{c}-430.7 * * \\
(-2.57)\end{array}$ & $\begin{array}{c}-263.4 * * \\
(-2.50)\end{array}$ & 119 \\
\hline Total loan from all banks & $\begin{array}{c}-601.0 * * \\
(-2.55)\end{array}$ & $\begin{array}{l}-211.9 \\
(-1.43)\end{array}$ & 119 \\
\hline Trade credit received & $\begin{array}{l}-67.6 \\
(-0.37)\end{array}$ & $\begin{array}{l}152.9 \\
(1.34)\end{array}$ & 119 \\
\hline Other credit & $\begin{array}{l}-111.2 \\
(-0.57)\end{array}$ & $\begin{array}{l}-58.1 \\
(-0.48)\end{array}$ & 119 \\
\hline Total firm debt & $\begin{array}{l}-779.8 \\
(-1.63)\end{array}$ & $\begin{array}{l}-117.1 \\
(-0.39)\end{array}$ & 119 \\
\hline \multicolumn{4}{|l|}{ Change of amount between 94-97 } \\
\hline Total loan from $\mathrm{ABC}$ and $\mathrm{RCC}$ & $\begin{array}{c}-256.0 * * \\
(-2.04)\end{array}$ & $\begin{array}{c}-203.5 * * * \\
(-2.71)\end{array}$ & 119 \\
\hline Total loan from all banks & $\begin{array}{c}-367.0 * * \\
(-2.41)\end{array}$ & $\begin{array}{c}-228.1^{* *} \\
(-2.50)\end{array}$ & 119 \\
\hline Trade credit received & $\begin{array}{l}31.0 \\
(0.34)\end{array}$ & $\begin{array}{c}148.5 * * * \\
(2.72)\end{array}$ & 119 \\
\hline Other credit & $\begin{array}{c}88.4 \\
(0.72)\end{array}$ & $\begin{array}{l}1.98 \\
(0.03)\end{array}$ & 119 \\
\hline Total firm debt & $\begin{array}{l}-247.5 \\
(-1.14)\end{array}$ & $\begin{array}{l}-77.6 \\
(-0.60)\end{array}$ & 119 \\
\hline
\end{tabular}

Notes:

1. Numbers in parentheses are t-ratios.

2. Significance level $0.1,0.05$ and 0.01 are noted by $* * *$, and $* * *$.

3. The regressors of the regressions generating these coefficients are the same as column (3) in Table 2. 
Table 8: Probit Regressions Examining the Determinants of Loan Performance (conditional on firm having a loan)

\begin{tabular}{|c|c|c|c|}
\hline \multirow[b]{3}{*}{ Independent variables $(\mathrm{dF} / \mathrm{dx})$} & \multicolumn{3}{|c|}{ Dependent Variable: 1=loan overdue } \\
\hline & \multicolumn{2}{|c|}{1997} & \multirow{2}{*}{$\frac{1994}{(3)}$} \\
\hline & $(1)$ & $(2)$ & \\
\hline \multicolumn{4}{|l|}{ Ownership Indicators } \\
\hline Privatized (between 94-97) & $\begin{array}{c}-0.163 * * * \\
(-2.96)\end{array}$ & $\begin{array}{c}-0.124 * * * \\
(-3.51)\end{array}$ & $\begin{array}{l}0.017 \\
(0.35)\end{array}$ \\
\hline \multicolumn{4}{|l|}{ Credit Worthiness } \\
\hline Credit rating & $\begin{array}{c}-0.049 * * * \\
(-3.56)\end{array}$ & $\begin{array}{c}-0.017^{*} \\
(-1.90)\end{array}$ & \\
\hline Firm manager's Education & $\begin{array}{l}0.013 \\
(1.09)\end{array}$ & $\begin{array}{l}0.006 \\
(0.88)\end{array}$ & $\begin{array}{l}-0.011 \\
(-0.86)\end{array}$ \\
\hline Firm manager's age & $\begin{array}{l}0.001 \\
(0.39)\end{array}$ & $\begin{array}{c}0.0002 \\
(0.12)\end{array}$ & $\begin{array}{l}-0.003 \\
(-0.92)\end{array}$ \\
\hline $\begin{array}{l}\text { Firm's age }(=1 \text { if established } \\
\text { after 1990) }\end{array}$ & $\begin{array}{l}-0.047 \\
(-0.70)\end{array}$ & $\begin{array}{l}-0.033 \\
(-0.97)\end{array}$ & $\begin{array}{l}0.097 \\
(1.09)\end{array}$ \\
\hline Sales (lagged) & & $\begin{array}{l}-0.003 \\
(-1.57)\end{array}$ & \\
\hline Debt asset ratio (lagged) & & $\begin{array}{l}-0.065 \\
(-1.37)\end{array}$ & \\
\hline Capital labor ratio (lagged) & & $\begin{array}{l}0.002 \\
(1.10)\end{array}$ & \\
\hline \multicolumn{4}{|l|}{ Other Control Variables } \\
\hline Bank type $(\mathrm{RCC}=0, \mathrm{ABC}=1)$ & $\begin{array}{l}0.043 \\
(0.91)\end{array}$ & $\begin{array}{l}0.020 \\
(0.76)\end{array}$ & $\begin{array}{l}-0.046 \\
(-0.97)\end{array}$ \\
\hline Province $($ Zhejiang=1) & $\begin{array}{c}-0.203 * * * \\
(-2.74)\end{array}$ & $\begin{array}{c}-0.108 * * * \\
(-2.61)\end{array}$ & $\begin{array}{c}-0.183 * * * \\
(-2.94)\end{array}$ \\
\hline Industry sectors & Yes & Yes & \\
\hline Observation & 161 & 140 & 158 \\
\hline Adj. R-squared & 0.25 & 0.36 & 0.10 \\
\hline
\end{tabular}

Notes:

1. Numbers in parentheses are t-ratios. Coefficients are $\mathrm{dF} / \mathrm{dx}$.

2. Significance level $0.1,0.05$ and 0.01 are noted by $* * *$, and $* * *$. Industry dummies are not shown.

3. Out of 20 private firm observations, only one has overdue loans in 1997, and none of the private firms have overdue loans in 1994. That is why we drop private indicator in the regressions. 
Table 9: Coefficients (t-ratios) of Ownership Indicators of Probit Models Examining the Determinants of Having Bank Loans in 1997 Conditional on Firms Demanding a Loan by Using Alternative Specifications (no loan $=0$ and having a loan $=1$ )

\begin{tabular}{|c|c|c|c|}
\hline Specification (bank's 1997 attributes) & Private & $\begin{array}{c}\text { Privatized } \\
\text { (between 94-97) }\end{array}$ & Sample size \\
\hline \multicolumn{4}{|l|}{$\begin{array}{l}\text { Bank manager's bonus/fixed-wage } \\
\text { ratio }\end{array}$} \\
\hline (1) Less than median $(0.875)$ & $\begin{array}{c}-0.859 * * * \\
(-4.25)\end{array}$ & $\begin{array}{c}-0.374 * * * \\
(-2.67)\end{array}$ & 125 \\
\hline (2) More than median & $\begin{array}{l}-0.040 \\
(-0.26)\end{array}$ & $\begin{array}{l}-0.096 \\
(-0.91)\end{array}$ & 157 \\
\hline \multicolumn{4}{|l|}{$\begin{array}{l}\text { Bank manager's weight on } \\
\text { profitability }\end{array}$} \\
\hline (3) Less than $100 \%$ & $\begin{array}{c}-0.714 * * \\
(-2.45)\end{array}$ & $\begin{array}{c}-0.320 * * \\
(-2.42)\end{array}$ & 105 \\
\hline (4) $100 \%$ & $\begin{array}{c}-0.321 * * \\
(-2.52)\end{array}$ & $\begin{array}{l}-0.057 \\
(-0.59)\end{array}$ & 176 \\
\hline $\begin{array}{l}\text { Bank manager's schooling } \\
\text { (5) Less than } 13 \text { years }\end{array}$ & $\begin{array}{c}-0.606^{* * *} \\
(-2.77)\end{array}$ & $\begin{array}{c}-0.256^{* *} \\
(-2.21)\end{array}$ & 105 \\
\hline (6) 13 years or above & $\begin{array}{c}-0.521 * * * \\
(-3.20)\end{array}$ & $\begin{array}{l}-0.044 \\
(-0.46)\end{array}$ & 177 \\
\hline \multicolumn{4}{|l|}{ Bank manager's experience } \\
\hline $\begin{array}{l}\text { (7) No previous experience as a } \\
\text { branch manager or vice manager }\end{array}$ & $\begin{array}{c}-0.602 * * * \\
(-3.37)\end{array}$ & $\begin{array}{l}-0.220^{*} \\
(-1.76)\end{array}$ & 133 \\
\hline $\begin{array}{l}\text { (8) Was a branch manager or vice } \\
\text { manager before }\end{array}$ & $\begin{array}{l}-0.349 \\
(-1.60)\end{array}$ & $\begin{array}{l}-0.271 * * \\
(-2.52)\end{array}$ & 135 \\
\hline \multicolumn{4}{|l|}{$\begin{array}{l}\text { Bank manager's years of residence in } \\
\text { the township }\end{array}$} \\
\hline (9) Less than 6 years & $\begin{array}{c}-0.380 * * \\
(-2.39)\end{array}$ & $\begin{array}{l}0.049 \\
(0.46)\end{array}$ & 141 \\
\hline (10) 6 years or above & $\begin{array}{c}-0.457 * * * \\
(-2.62)\end{array}$ & $\begin{array}{c}-0.313 * * * \\
(-2.94)\end{array}$ & 146 \\
\hline
\end{tabular}

Notes:

1. Numbers in parentheses are t-ratios. Coefficients are $\mathrm{dF} / \mathrm{dx}$.

2. Significance level $0.1,0.05$ and 0.01 are noted by $*, * *$, and $* * *$.

3. The regressors of the regressions generating these coefficients are the same as column (3) in Table 2 .

4. The number of observations may differ due to missing values of bank attributes. The median may not equally divide the sample because most of the bank attributes are discrete variables. 
Table 10: Coefficients (t-ratios) of PRIVATIZED Firm Indicators of Probit Models Testing Omitted Variable Bias

Credit Access in 1994

Firms divided on basis of 1997 bank attributes

$1=$ a loan in 1994 ;

$0=$ otherwise

Independent variables

are 1994 values

\section{Bank manager's bonus/fixed-wage ratio}

(1) Less than median

(2) More than median

Bank manager's weight on profitability

(3) Less than $100 \%$

(4) $100 \%$

Bank manager's schooling

(5) Less than the median

(6) Above the median

Bank manager's experience

(7) No previous experience as a branch manager or vicemanager

(8) Was a branch manager or vice manager before

Bank manager's years of residence in the township

(9) Less than 6 years

(10) 6 years or above
0.039

$(0.37)$

$-0.075$

$(-0.77)$

0.110

$(0.93)$

0.001

$(0.02)$

0.018

$(0.23)$

0.065

(0.48)

$-0.010$

$(-0.10)$

0.054

(0.60)

$0.237^{* *}$

(2.24)

$-0.136$

$(-1.41)$

\section{Fixed-effect model}

1=a loan increase 1994-1997; Sample $0=$ otherwise size

for

Independent variables are first both differences, 1997-1994
111

121

$$
\begin{gathered}
-0.307 * * * \\
(-2.91) \\
-0.096 \\
(-1.06)
\end{gathered}
$$

(-1.06)

$-0.446^{* * *}$

$(-3.70)$

$-0.171 * *$

$(-1.96)$

$-0.242 * * *$

$(-3.05)$

$-0.188$

$(-1.49)$

$-0.325^{* * *}$

$(-2.96)$

$-0.229 * *$

$(-2.52)$

$-0.104$

$(-1.00)$

$-0.266^{* * *}$

$(-2.86)$
91

141

171

66

103

129

114

121

\section{Notes:}

1. Numbers in parentheses are t-ratios. Coefficients are $\mathrm{dF} / \mathrm{dx}$.

2. Significance level $0.1,0.05$ and 0.01 are noted by $*, * *$, and $* * *$.

3. The regressors of the regressions generating coefficients in column 1 are the same as column (3) in Table 2, but those generating coefficients in column 1 include only the privatization indicator, and the change of manager's education and age.

4. The number of observations may differ due to missing values of bank attributes. The median may not equally divide the sample because most of the bank attributes are discrete variables.

5. Regressions in Table 10 have more missing values than Table 9 because we use 1994 information in Table 10, which has more missing values than 1997 information. 
William Davidson Institute Working Paper 517

Table A1: Sample Firm Attributes: Mean and Standard Deviation

\begin{tabular}{|c|c|c|c|c|c|c|}
\hline & \multicolumn{3}{|c|}{1994} & \multicolumn{3}{|c|}{1997} \\
\hline & $\mathrm{TE}$ & $\begin{array}{c}\text { Privatized } \\
1994-97\end{array}$ & Private & TE & $\begin{array}{c}\text { Privatized } \\
1994-97\end{array}$ & Private \\
\hline Number of observations & 39 & 81 & 32 & 39 & 81 & 32 \\
\hline Employment & $\begin{array}{c}261 \\
(251)\end{array}$ & $\begin{array}{c}200 \\
(283)\end{array}$ & $\begin{array}{c}90 \\
(88)\end{array}$ & $\begin{array}{c}278 \\
(308)\end{array}$ & $\begin{array}{l}166 \\
(272)\end{array}$ & $\begin{array}{l}230 \\
(665)\end{array}$ \\
\hline Sales & $\begin{array}{c}16.2 \\
(23.1)\end{array}$ & $\begin{array}{c}9.8 \\
(17.7)\end{array}$ & $\begin{array}{c}6.1 \\
(12.1)\end{array}$ & $\begin{array}{c}26.7 \\
(46.7)\end{array}$ & $\begin{array}{c}14.8 \\
(38.0)\end{array}$ & $\begin{array}{c}21.0 \\
(62.8)\end{array}$ \\
\hline Profits & $\begin{array}{l}0.71 \\
(1.9)\end{array}$ & $\begin{array}{l}0.20 \\
(0.7)\end{array}$ & $\begin{array}{l}0.25 \\
(1.0)\end{array}$ & $\begin{array}{l}1.95 \\
(5.1)\end{array}$ & $\begin{array}{l}0.35 \\
(1.0)\end{array}$ & $\begin{array}{l}1.16 \\
(4.9)\end{array}$ \\
\hline $\begin{array}{l}\text { Percentage of firms with } \\
\text { profit }<0\end{array}$ & $14 \%$ & $24 \%$ & $20 \%$ & $29 \%$ & $30 \%$ & $24 \%$ \\
\hline Assets $^{1}$ & $\begin{array}{c}14.4 \\
(19.1)\end{array}$ & $\begin{array}{c}7.9 \\
(10.1)\end{array}$ & $\begin{array}{c}3.8 \\
(5.0)\end{array}$ & $\begin{array}{c}26.5 \\
(47.2)\end{array}$ & $\begin{array}{c}10.2 \\
(14.8)\end{array}$ & $\begin{array}{c}7.2 \\
(10.2)\end{array}$ \\
\hline Physical capital stock & $\begin{array}{l}5.3 \\
(6.4)\end{array}$ & $\begin{array}{l}2.8 \\
(4.4)\end{array}$ & $\begin{array}{l}1.3 \\
(2.3)\end{array}$ & $\begin{array}{c}9.2 \\
(13.7)\end{array}$ & $\begin{array}{c}3.3 \\
(5.5)\end{array}$ & $\begin{array}{c}3.0 \\
(4.6)\end{array}$ \\
\hline Debts $^{1}$ & $\begin{array}{l}5.8 \\
(7.2)\end{array}$ & $\begin{array}{c}4.4 \\
(6.1)\end{array}$ & $\begin{array}{c}2.0 \\
(3.0)\end{array}$ & $\begin{array}{c}9.0 \\
(12.9)\end{array}$ & $\begin{array}{c}5.6 \\
(8.0)\end{array}$ & $\begin{array}{c}3.1 \\
(4.4)\end{array}$ \\
\hline Equity $^{1}=$ assets - debts & $\begin{array}{c}8.6 \\
(17.0)\end{array}$ & $\begin{array}{c}3.5 \\
(5.0)\end{array}$ & $\begin{array}{c}1.8 \\
(3.2)\end{array}$ & $\begin{array}{c}17.5 \\
(39.1)\end{array}$ & $\begin{array}{c}4.6 \\
(7.9)\end{array}$ & $\begin{array}{c}4.1 \\
(6.3)\end{array}$ \\
\hline Credit Ratings & & & & & & \\
\hline $\mathrm{RCC}$ & $\begin{array}{c}3.7 \\
(1.5)\end{array}$ & $\begin{array}{c}3.3 \\
(1.7)\end{array}$ & $\begin{array}{c}2.8 \\
(1.7)\end{array}$ & $\begin{array}{c}3.9 \\
(1.5)\end{array}$ & $\begin{array}{c}3.6 \\
(1.6)\end{array}$ & $\begin{array}{c}3.9 \\
(1.7)\end{array}$ \\
\hline $\mathrm{ABC}$ & $\begin{array}{c}4 \\
(1.4)\end{array}$ & $\begin{array}{c}3.4 \\
(1.4)\end{array}$ & $\begin{array}{c}2.7 \\
(2.1)\end{array}$ & $\begin{array}{c}3.7 \\
(1.5)\end{array}$ & $\begin{array}{c}3.2 \\
(1.4)\end{array}$ & $\begin{array}{c}3.4 \\
(2.0)\end{array}$ \\
\hline Manger & & & & & & \\
\hline Education & $\begin{array}{l}11.0 \\
(2.2)\end{array}$ & $\begin{array}{l}10.6 \\
(2.2)\end{array}$ & $\begin{array}{l}10.1 \\
(2.2)\end{array}$ & $\begin{array}{l}11.1 \\
(2.3)\end{array}$ & $\begin{array}{l}10.7 \\
(2.2)\end{array}$ & $\begin{array}{l}10.2 \\
(2.3)\end{array}$ \\
\hline Age & $\begin{array}{l}43.5 \\
(7.1)\end{array}$ & $\begin{array}{l}43.7 \\
(9.0)\end{array}$ & $\begin{array}{l}40.7 \\
(8.4)\end{array}$ & $\begin{array}{l}44.6 \\
(8.5)\end{array}$ & $\begin{array}{l}44.9 \\
(7.2)\end{array}$ & $\begin{array}{l}42.7 \\
(8.8)\end{array}$ \\
\hline
\end{tabular}

Notes:

1. Assets, debts and equity have only 129 observations, because of missing observations of assets in 1994 . 
William Davidson Institute Working Paper 517

Table A2: Bank Manger's Attributes $(\mathrm{N}=118)$

\begin{tabular}{lcc} 
Specification (bank's 1997 attributes) & 1994 & 1997 \\
\hline & & 0.77 \\
Bank manager's bonus/fixed-wage ratio & 0.62 & $(0.36)$ \\
& $(0.31)$ & 0.59 \\
$\begin{array}{l}\text { Bank manager's weight on profitability } \\
\text { (1if 100 percent on profitability) }\end{array}$ & 0.26 & $(0.49)$ \\
$\begin{array}{l}\text { Bank manager's schooling (years) } \\
\text { Bank manager's experience } \\
\text { (1 if having been a bank manager }\end{array}$ & $(0.44)$ & 12.6 \\
before this job) & 12.0 & $(1.63)$ \\
$\begin{array}{l}\text { Bank manager's years of residence in } \\
\text { the township }\end{array}$ & 0.43 & 0.53 \\
\end{tabular}




\section{DAVIDSON INSTITUTE WORKING PAPER SERIES - Most Recent Papers}

The entire Working Paper Series may be downloaded free of charge at: www.wdi.bus.umich.edu

CURRENT AS OF $12 / 4 / 02$

\begin{tabular}{|c|c|c|}
\hline Publication & Authors & Date \\
\hline $\begin{array}{l}\text { No. 517: Bank Discrimination in Transition Economies: Ideology, } \\
\text { Information or Incentives? }\end{array}$ & Loren Brandt and Hongbin Li & Oct. 2002 \\
\hline $\begin{array}{l}\text { No. 516: Ex-ante Evaluation of Conditional Cash Transfer Programs: } \\
\text { The Case of Bolsa Escola }\end{array}$ & $\begin{array}{l}\text { François Bourguignon, Francisco } \\
\text { H. G. Ferreira and Phillippe G. } \\
\text { Leite }\end{array}$ & Sep. 2002 \\
\hline No. 515: Missed Expectations: The Argentine Convertibility & $\begin{array}{l}\text { Sebastian Galiani, Daniel } \\
\text { Heymann and Mariano Tommasi }\end{array}$ & Nov. 2002 \\
\hline $\begin{array}{l}\text { No. 514: Job Reallocation and Productivity Growth under Alternative } \\
\text { Economic Systems and Policies: Evidence from the Soviet Transition }\end{array}$ & J. David Brown and John S. Earle & Nov. 2002 \\
\hline $\begin{array}{l}\text { No. 513: Cross-Border Trading as a Mechanism for Capital Flight: } \\
\text { ADRs and the Argentine Crisis }\end{array}$ & $\begin{array}{l}\text { Sebastian Auguste, Kathryn M.E. } \\
\text { Dominguez, Herman Kamil and } \\
\text { Linda L. Tesar }\end{array}$ & Nov. 2002 \\
\hline $\begin{array}{l}\text { No. 512: Embracing the Market: Entry into Self-Employment in } \\
\text { Transitional China, } 1978-1996\end{array}$ & Xiaogang Wu & Sep. 2002 \\
\hline $\begin{array}{l}\text { No. 511: Opening the Capital Account of Transition Economies: How } \\
\text { Much and How Fast }\end{array}$ & $\begin{array}{l}\text { Daniel Daianu and Radu } \\
\text { Vranceanu }\end{array}$ & Sep. 2002 \\
\hline $\begin{array}{l}\text { No. 510: Bridging "the Great Divide": Countering Financial Repression } \\
\text { in Transition }\end{array}$ & Patrick Conway & May 2002 \\
\hline $\begin{array}{l}\text { No. 509: Change the Regime - Change the Money: Bulgarian } \\
\text { Banknotes, 1885-2001 }\end{array}$ & Adrian E. Tschoegl & May 2002 \\
\hline $\begin{array}{l}\text { No. 508: Differential Rewards to, and Contributions of, Education in } \\
\text { Urban China's Segmented Labor Markets }\end{array}$ & $\begin{array}{l}\text { Margaret Maurer-Fazio and Ngan } \\
\text { Dinh }\end{array}$ & June 2002 \\
\hline $\begin{array}{l}\text { No. 507: Balassa-Samuelson Effect in Transition Economies: The Case } \\
\text { of Slovenia }\end{array}$ & Boštjan Jazbec & Oct. 2002 \\
\hline $\begin{array}{l}\text { No. 506: Explaining Gender Differences in Unemployment with Micro } \\
\text { Data on Flows in Post-Communist Economies }\end{array}$ & $\begin{array}{l}\text { Jana Stefanová Lauerová and } \\
\text { Katherine Terrell }\end{array}$ & Sep. 2002 \\
\hline No. 505: Bank Performance in Transition Economies & $\begin{array}{l}\text { Steven Fries, Damien Neven and } \\
\text { Paul Seabright }\end{array}$ & Sep. 2002 \\
\hline $\begin{array}{l}\text { No. 504: Does the Balassa-Samuelson Hypothesis Hold for Asian } \\
\text { Countries? An Empirical Analysis using Panel Data Cointegration Tests }\end{array}$ & Imed Drine and Christophe Rault & Sep. 2002 \\
\hline No. 503: Job Growth in Early Transition: Comparing Two Paths & $\begin{array}{l}\text { Štěpán Jurajda and Katherine } \\
\text { Terrell }\end{array}$ & Aug. 2002 \\
\hline $\begin{array}{l}\text { No. 502: Job Creation, Destruction and Transition in Poland, 1988- } \\
\text { 1998: Panel Evidence }\end{array}$ & $\begin{array}{l}\text { John E. Jackson and Bogdan } \\
\text { Mach }\end{array}$ & June 2002 \\
\hline $\begin{array}{l}\text { No. 501: Competition, Innovation and Growth in Transition: Exploring } \\
\text { the Interactions between Policies }\end{array}$ & $\begin{array}{l}\text { Philippe Aghion, Wendy Carlin } \\
\text { and Mark Schaffer }\end{array}$ & Mar. 2002 \\
\hline No. 500: Women in the LAC Labor Market: The Remarkable 1990's & $\begin{array}{l}\text { Suzanne Duryea, Alejandra Cox } \\
\text { Edwards and Manuelita Ureta }\end{array}$ & June 2001 \\
\hline $\begin{array}{l}\text { No. 499: Human Capital, Growth and Inequality in Transition } \\
\text { Economies }\end{array}$ & Michael Spagat & July 2002 \\
\hline No. 498: Understanding Czech Long-Term Unemployment & $\begin{array}{l}\text { Štěpán Jurajda and Daniel } \\
\text { Münich }\end{array}$ & Aug. 2002 \\
\hline $\begin{array}{l}\text { No. 497: Rent Seeking and Government Ownership of Firms: An } \\
\text { Application to China's Township-Village Enterprises }\end{array}$ & Jiahua Che & Sep. 2002 \\
\hline No. 496: Labor Market Flexibility in Central and East Europe & Jan Svejnar & Aug. 2002 \\
\hline $\begin{array}{l}\text { No. 495: When Information Dominates Comparison: A Panel Data } \\
\text { Analysis Using Russian Subjective Data }\end{array}$ & Claudia Senik & May 2002 \\
\hline No. 494: Corruption and Cross-Border Investment: Firm Level Evidence & $\begin{array}{l}\text { Beata K. Smarzynska and Shang- } \\
\text { Jin Wei }\end{array}$ & Aug. 2002 \\
\hline $\begin{array}{l}\text { No. 493: Modeling Sequences of Long Memory Positive Weakly } \\
\text { Stationary Random Variables }\end{array}$ & Dmitri Koulikov & Aug. 2002 \\
\hline $\begin{array}{l}\text { No. 492: Effects of Ownership and Financial Status on Corporate } \\
\text { Environmental Performance }\end{array}$ & $\begin{array}{l}\text { Dietrich Earnhart and Lubomír } \\
\text { Lízal }\end{array}$ & 002 \\
\hline
\end{tabular}

